\title{
Long-term effects of lime and phosphogypsum application on tropical no-till soybean-oat-sorghum rotation and soil chemical properties
}

\author{
Claudio Hideo Martins da Costa, Carlos Alexandre Costa Crusciol* \\ São Paulo State University (UNESP), College of Agricultural Science, Department of Crop Science, Lageado Experimental Farm, José Barbosa de Barros Street, \\ 1780, P.O. Box 237, 18610-307 Botucatu, São Paulo, Brazil
}

\section{A R T I C L E I N F O}

\section{Article history:}

Received 9 April 2015

Received in revised form

27 November 2015

Accepted 4 December 2015

Available online 30 December 2015

\section{Keywords:}

Soil corrective

Soil conditioner

Glycine max

Sorghum bicolor

Avena strigosa

Brazilian tropical soils

\begin{abstract}
A B S T R A C T
Root growth, nutrition and crop yield can be affected by soil chemical modifications caused by superficial limestone and phosphogypsum application in a no-till system. Using this approach, this study was conducted in southeastern Brazil, continuing an experiment that has been on-going since 2002 with the objective of evaluating the residual effects of the surface application of lime and phosphogypsum on the soil chemical characteristics and the root growth, nutrition and yield of soybean, black oat and sorghum in a dry winter region cultivated in 2008/2009 and 2009/2010. The experimental design was a randomized block with 4 replications. The treatments were applied in November 2004 and were as follows: original conditions, limestone application (2000 kg ha-1), phosphogypsum application (2100 kg ha $\left.{ }^{-1}\right)$, and limestone $\left(2000 \mathrm{~kg} \mathrm{ha}^{-1}\right)+$ phosphogypsum $\left(2100 \mathrm{~kg} \mathrm{ha}^{-1}\right)$ application. Superficial liming with or without phosphogypsum reduced the surface and subsurface soil acidity 5 years after application in the no-till system. The movement of $\mathrm{Ca}^{2+}$ and $\mathrm{Mg}^{2+}$ from the surface layer into the subsoil over time was evident. The phosphogypsum application associated with liming increased the $\mathrm{Ca}^{2+}$ levels throughout the soil profile. Liming maintained high levels of $\mathrm{Mg}^{2+}$ throughout the soil profile with or without phosphogypsum application. The organic matter content increased with liming with or without phosphogypsum, indicating that in the long term, these practices can increase the $C$ accumulation. Phosphogypsum application had a residual effect on the $\mathrm{SO}_{4}$-S levels, and high sulphate concentrations were observed in the subsoil after 5 years. Superficial liming improved crop nutrition and, when associated with phosphogypsum, increased Ca absorption by soybean and sorghum, as reflected in the increased yields of these crops.
\end{abstract}

(c) 2015 Elsevier B.V. All rights reserved.

\section{Introduction}

Soil acidity is one of the factors limiting crop production, especially in tropical areas such as Brazil. The total area that is affected by acidity is estimated to be 4 billion ha, representing $30 \%$ of the cropland worldwide (Sumner and Noble, 2003). The affected areas are mostly within countries located in the tropics; they comprise primarily Oxisols and Ultisols in South America and Oxisols in Africa (Narro et al., 2001). In Brazil, the "cerrado" (tropical savannah) is the main grain-producing region and occupies approximately 205 million ha, which is approximately $23 \%$ of the country. The soils in this region are predominantly Oxisols (46\%), Ultisols (15\%) and Entisols (15\%), with low fertility, high aluminium saturation, and high P-fixation capacity (Fageria and Stone, 1999). Low fertility is characteristic of acidic soil; therefore, the correction of these soils is

\footnotetext{
* Corresponding author. Fax: +55 1438807161.

E-mail address: crusciol@fca.unesp.br (C.A.C. Crusciol).
}

very important for the proper growth of crops (Soratto and Crusciol, 2008a,b; Soratto et al., 2010).

Liming is the most commonly used practice to neutralize soil acidity and restore production capacity, increase nutrient availability, and reduce levels of toxic elements (Caires et al., 2001; Pavan and Oliveira, 2000). In conventional tillage systems, lime is incorporated into the soil by ploughing and disking. This practice breaks up the soil aggregates, exposes the soil and increases susceptibility to erosion (Bronick and Lal, 2005). Additionally, aggregate disruption promotes the mineralization of previously protected organic matter (Caires et al., 2006a; Westerhof et al., 1999). Therefore, the interest in surface liming to control soil acidity since the implementation of no-till systems is mainly based on preserving the physical properties of the soil (Caires et al., 2011) and maintaining agricultural sustainability in tropical and subtropical regions (Caires et al., 2005).

However, in the short term, the effects of superficial liming are restricted to the soil surface (Pavan and Oliveira, 2000) because without incorporation, there is less contact between the particles 
of lime and soil colloids (Caires et al., 2005). The neutralization of the soil acidity in the subsurface with limestone is generally slow, particularly in variably charged soils (Ernani et al., 2004), because the movement of limestone to greater depths varies according to the time, dose, form, and frequency of application; soil type; climate; acid fertilizer management and crop system (Blevins et al., 1978; Caires et al., 2008b,c, 2005; de Oliveira and Pavan, 1996).

Phosphogypsum is more soluble than limestone and is composed mostly of calcium sulphate $\left(\mathrm{CaSO}_{4} \cdot \mathrm{H}_{2} \mathrm{O}\right)$; however, its addition does not change the soil $\mathrm{pH}$. The phosphogypsum that is applied to the soil surface moves along the profile under the influence of percolating water (Caires et al., 1999). As a result, there is an increase in the supply of calcium and a reduction in the aluminium toxicity in the subsoil (Caires et al., 2003, 1999). Phosphogypsum is therefore an alternative for improving the root environment in the subsoil and can be used in acidic soils as a supplement for liming (Caires et al., 2003).

In the subtropical region of Brazil, where the rainfall is well distributed throughout the year, there are several reports of a lack of response of crops to the application of soil acidity correctives in no-till systems (Caires et al., 2011, 2008b,c, 2006b; Moreira et al., 2001). These findings have been attributed to the greater accumulation of organic matter and nutrients in the surface that reduce the activity of $\mathrm{Al}$ and consequently its toxicity by forming $\mathrm{Al}$-organic complexes and to the increased ionic strength of the soil solution (Nolla and Anghinoni, 2006; Vieira et al., 2009).

It is possible the vast majority of the cerrado biome can experience increases in grain yield and fibre production with lime and phosphogypsum application in no-till systems, even on the surface, unlike what has been observed elsewhere in the subtropical region. This possibility exists because in these regions, the vast majority of cultivated areas have a low organic matter content and a low amount of straw on the surface, leading to low water storage and high evaporation of the soil water, respectively.

Thus, the probable soil acidity correction, aluminium reduction levels and base saturation elevation, especially that of calcium, in the soil profile in a short time will enable greater root depth due to the mechanisms that promote the movement of compounds produced by the dissociation of limestone and phosphogypsum. This condition will increase the water stress tolerance of plants when dry spells induce water stress, especially during off-season cultivation.

The soil acidity correction dynamics in the soil surface in no-till systems and the benefits of the joint application of limestone and phosphogypsum in long-term experiments remain poorly investigated, especially in cerrado conditions in tropical regions. However, this knowledge is important for adjusting the limestone and phosphogypsum recommendations for annual crops in no-till systems.

This study evaluated the changes in soil chemical attributes and the root growth, nutrition and productivity of soybean, black oat and sorghum resulting from limestone and phosphogypsum surface application in an established no-till system in a tropical region.

\section{Materials and methods}

\subsection{Site description}

This experiment was conducted in Botucatu, State of São Paulo, southeastern Brazil, $\left(48^{\circ} 23^{\prime} \mathrm{W}, 22^{\circ} 51^{\prime} \mathrm{S}\right.$ and 765 masl) during the $2008 / 2009$ and $2009 / 2010$ growing seasons. Soil at this location is classified as Rhodic Ferralsol (FAO, 2006) [kaolinitic, thermic Typic Haplorthox (Soil Survey Staff, 2014), with sandy loam texture] and had been managed since 2002 in a no-till system as follows: growing season 2002/2003, rice in the summer and black oat in the fall; growing season $2003 / 2004$, bean in the summer and black oat in the fall; growing seasons 2004/2005 and 2005/2006, peanut in the summer and oat in the fall; and growing seasons 2006/2007 and $2007 / 2008$, intercropped corn with Urochloa ruziziensis.

The climate according to Köeppen's classification is Cwa (tropical, with a dry winter and hot, rainy summer). Monthly mean values of rainfall and temperature during the experiment are shown in Fig. 1.

At the beginning of the experiment (October 2002) and before lime and phosphogypsum reapplication (August 2004), the chemical attributes of the topsoil $(0-0.20 \mathrm{~m})$ were determined (Table 1$)$. In August 2004, soil samples were collected (0-0.20 m) for soil particle size distribution determination with the following results: sand, silt, and clay contents of 540,110 , and $350 \mathrm{~g} \mathrm{~kg}^{-1}$, respectively. In the subsoil $(0.20-0.40 \mathrm{~m})$, the clay content was $360 \mathrm{~g} \mathrm{~kg}^{-1}$. The bulk density at depth $0-0.20 \mathrm{~m}$ was $1.128 \mathrm{Mg} \mathrm{m}^{-3}$.

\subsection{Experimental design and treatments}

The experimental design was a randomized complete block with 4 replications. The experimental units were $5.4 \times 9 \mathrm{~m}$. The treatments were as follows: original condition, lime application (Eq. (1), to increase the base saturation to 70\%), phosphogypsum application (Eq. (4)), and combined lime (Eq. (1), to increase the base saturation to $70 \%$ ) plus phosphogypsum (Eq. (4)) application.

At the beginning of the experiment (October 15, 2002), limestone was applied superficially at a rate of $2700 \mathrm{~kg} \mathrm{ha}^{-1}$. Phosphogypsum was applied one day after liming at a rate of $2100 \mathrm{~kg} \mathrm{ha}^{-1}$. The reapplication was based on a soil analysis that was carried out in August 2004, where the base saturation in the treatment in which the limestone was applied reached $50 \%$, the preestablished critical level for the reapplication. Thus, on November 19,2004 , the application of limestone and phosphogypsum was performed at rates of $2000 \mathrm{~kg} \mathrm{ha}^{-1}$ and $2100 \mathrm{~kg} \mathrm{ha}^{-1}$, respectively.

\subsection{Dolomitic limestone and phosphogypsum characteristics}

The dolomitic limestone composition was $23.3 \% \mathrm{CaO}, 17.5 \%$ $\mathrm{MgO}$, and $71 \%$ effective calcium carbonate equivalence (ECCE). In a physical analysis of the dolomitic limestone, 68.8, 92.4, and 99.7\% of the particles passed through 50-, 20-, and 10-mesh sieves, respectively. The composition of phosphogypsum $\left(\mathrm{CaSO}_{4} \cdot 2 \mathrm{H}_{2} \mathrm{O}\right)$, a by-product obtained from the Brazilian phosphoric acid industry, was $20 \% \mathrm{Ca}, 16 \% \mathrm{~S}$, and a small residue of $0.1 \% \mathrm{P}$ and $\mathrm{F}$. In a physical analysis of the phosphogypsum, 60 and $90 \%$ of the particles were retained in 50- and 20-mesh sieves, respectively.

The dolomitic limestone rate (LR) was calculated to increase the base saturation in topsoil $(0-20 \mathrm{~cm})$ to $70 \%$ according to Eq. (1):

$\mathrm{LR}\left(\mathrm{kg} \mathrm{ha}^{-1}\right)=\frac{\left(\mathrm{BS}_{2}-\mathrm{BS}_{1}\right)(\mathrm{CEC} / \mathrm{BD})}{\mathrm{ECCE} / 100}$

where $\mathrm{BS}_{2}$ is the estimated base saturation (70\%) and $\mathrm{BS}_{1}$ is the base saturation as measured in the soil analysis as in Eq. (2):

$\mathrm{BS}_{1}(\%)=\frac{\left(\mathrm{Ca}_{\mathrm{ex}}+\mathrm{Mg}_{\mathrm{ex}}+\mathrm{K}_{\mathrm{ex}}\right) 100}{\mathrm{CEC}}$

where $\mathrm{Ca}_{\mathrm{ex}}, \mathrm{Mg}_{\mathrm{ex}}$, and $\mathrm{K}_{\mathrm{ex}}$ are basic exchangeable cations, $\mathrm{BD}$ is bulk density at $0-0.20 \mathrm{~m}$ depth, and CEC is the total cation exchange capacity, as calculated by Eq. (3):

$$
\begin{aligned}
& \mathrm{CEC}\left(\mathrm{cmol}_{\mathrm{C}} \mathrm{kg}^{-1}\right)=\mathrm{Ca}_{\mathrm{ex}} \\
& \quad+\mathrm{Mg}_{\mathrm{ex}}+\mathrm{K}_{\mathrm{ex}}+\text { totalacidityatpH7.0 }(\mathrm{H}+\mathrm{Al})
\end{aligned}
$$

The phosphogypsum rate (GR) was calculated using Eq. (4):

$\mathrm{GR}\left(\mathrm{kg} \mathrm{ha}^{-1}\right)=6 \mathrm{CL}($ vanRaijet al., 1997)

where CL is the clay content $\left(\mathrm{g} \mathrm{kg}^{-1}\right)$ in the soil layer from 20 to $40 \mathrm{~cm}$. 


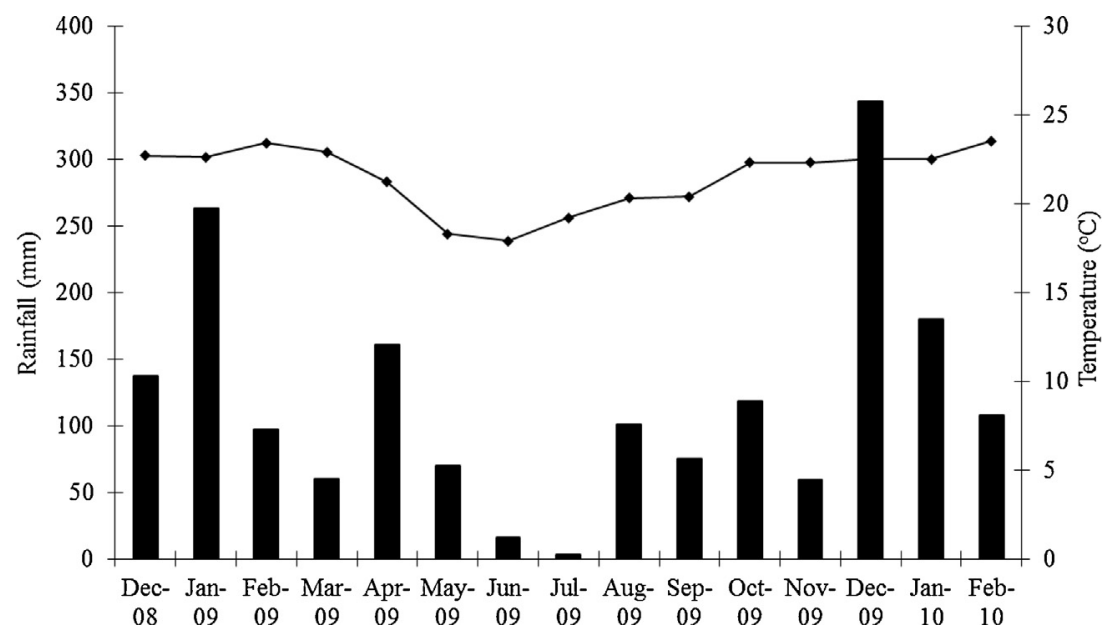

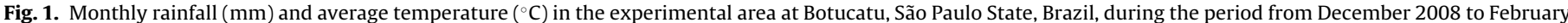
2010.

Table 1

Chemical characteristics of the soil before the experiment (October 2002) and before the last application (August 2004).

\begin{tabular}{|c|c|c|c|c|c|c|c|c|c|c|}
\hline Depth (m) & $\begin{array}{l}\mathrm{pH} \\
\left(\mathrm{CaCl}_{2}\right)\end{array}$ & $\begin{array}{l}\text { SOM } \\
\left(\mathrm{g} \mathrm{kg}^{-1}\right)\end{array}$ & $\begin{array}{l}\mathrm{P}(\text { resin }) \\
\left(\mathrm{mg} \mathrm{kg}^{-1}\right)\end{array}$ & $\begin{array}{l}\mathrm{H}+\mathrm{Al} \\
\left(\mathrm{mmol}_{\mathrm{c}} \mathrm{kg}^{-1}\right)\end{array}$ & $\begin{array}{l}\mathrm{Al} \\
\left(\mathrm{mmol}_{\mathrm{c}} \mathrm{kg}^{-1}\right)\end{array}$ & $\begin{array}{l}\mathrm{K} \\
\left(\mathrm{mmol}_{\mathrm{c}} \mathrm{kg}^{-1}\right)\end{array}$ & $\begin{array}{l}\mathrm{Ca} \\
\left(\mathrm{mmol}_{\mathrm{c}} \mathrm{kg}^{-1}\right)\end{array}$ & $\begin{array}{l}\mathrm{Mg} \\
\left(\mathrm{mmol}_{\mathrm{c}} \mathrm{kg}^{-1}\right)\end{array}$ & $\begin{array}{l}\text { CEC } \\
\left(\mathrm{mmol}_{\mathrm{c}} \mathrm{kg}^{-1}\right)\end{array}$ & BS (\%) \\
\hline \multicolumn{11}{|c|}{ October 2002} \\
\hline $0-0.20$ & 4.2 & 24 & 10 & 42 & 7.3 & 1.4 & 16 & 6 & 65 & 37 \\
\hline \multicolumn{11}{|c|}{ August 2004} \\
\hline $0-0.20$ & 4.9 & 30 & 39 & 39 & 2.6 & 1.2 & 27 & 11.0 & 79 & 50 \\
\hline
\end{tabular}

\subsection{Crop characteristics and management}

Soybean (Glycine max) was sown on December 11, 2008, and October 29, 2009, using the cultivars MGBR-46 and CD 216, respectively. The row spacing was $0.45 \mathrm{~m}$ with approximately 22 and 20 seeds $\mathrm{m}^{-1}$, respectively. The seeds were treated with a fungicide (Vitavax + thiram $-50+50 \mathrm{~g}$ of the active ingredient for every $100 \mathrm{~kg}$ of seed) and an inoculant (Bradyrhizobium japonicum). The base fertilization consisted of $250 \mathrm{~kg} \mathrm{ha}^{-1}$ of 04-20-20 NPK formula according to the results of a soil chemical analysis and soybean crop recommendations (van Raij et al., 1997). In both years, phytosanitary measures were taken based on soybean recommendations and requirements.

Black oat (Avena strigosa) and sorghum (Sorghum bicolor (L.) Moench) were sown on June 22, 2009, and March 08, 2010, using the cultivar "Comum" and the hybrid AG 1020, respectively. The row spacing was 0.17 and $0.60 \mathrm{~m}$, respectively, with seed rates of $60 \mathrm{~kg} \mathrm{ha}^{-1}$ and 18 seeds $\mathrm{m}^{-1}$, respectively. The seeds were treated with a fungicide (Vitavax + thiram $-50+50 \mathrm{~g}$ of the active ingredient for every $100 \mathrm{~kg}$ of seed). In both crops, no fertilizer was applied, and phytosanitary measures were taken based on recommendations and requirements.

Soybeans were harvested on April 24, 2009, and February 24, 2010; black oat and sorghum were harvested on October 19, 2009, and July 21, 2010, respectively. Samples were taken for the evaluation of the yield components and final yield $\left(130 \mathrm{~g} \mathrm{~kg}^{-1}\right.$ moisture content). The yield components were plant population, number of pods per plant, number of grains per pod and 100-grain weight for soybean, and panicles per $\mathrm{m}^{2}$, grains per panicle, and 1000-grain weight for black oat and sorghum.

\subsection{Soil sampling and chemical analysis}

Soil samples were taken 48 and 60 months after lime and phosphogypsum reapplication at depths of $0-0.05,0.05-0.10$,
$0.10-0.20,0.20-0.40$, and $0.40-0.60 \mathrm{~m}$. Seven subsamples were taken randomly from the plot area of each of the plots between rows and combined into one composite sample. Sample analyses included the following. The soil $\mathrm{pH}$ was determined in a $0.01 \mathrm{~mol} \mathrm{~L}^{-1} \mathrm{CaCl}_{2}$ suspension (1:2.5 soil/solution). The soil organic matter was determined by the Walkley-Black method (Walkley and Black, 1934). The total acidity at $\mathrm{pH} 7.0(\mathrm{H}+\mathrm{Al})$ was estimated by the SMP-buffer solution method (van Raij et al., 2001). The exchangeable Al was extracted with neutral $1 \mathrm{~mol} \mathrm{~L}^{-1} \mathrm{KCl}$ at a $1: 10$ soil/solution ratio and determined by titration with a $0.025 \mathrm{~mol} \mathrm{~L}^{-1} \mathrm{NaOH}$ solution. Phosphorus and exchangeable $\mathrm{Ca}, \mathrm{Mg}$ and $\mathrm{K}$ were extracted with ion-exchange resins; in the extract, $\mathrm{P}$ was determined colorimetrically, and cations by atomic absorption spectrometry (van Raij et al., 2001). Using the exchangeable bases and total acidity at $\mathrm{pH} 7.0(\mathrm{H}+\mathrm{Al})$ results, the base saturation values were calculated (van Raij et al., 2001). The soil $\mathrm{SO}_{4}-\mathrm{S}$ analyses were performed through extraction by calcium phosphate $0.01 \mathrm{~mol} \mathrm{~L}^{-1}$ at a $1: 2.5 \mathrm{soil} /$ solution ratio and later determined by the turbidimetric method by precipitating sulphate as $\mathrm{BaSO}_{4}$ (Vitti, 1988).

\subsection{Soybean root sampling and analyses}

The soybean root system was sampled when $50 \%$ of the plants of each subplot were flowering. A $4.5-\mathrm{cm}$ diameter galvanizedsteel auger was used for sampling at depths of $0-0.05,0.05-0.10$, $0.10-0.20,0.20-0.40$, and $0.40-0.60 \mathrm{~m}$. For each layer, five subsamples were collected from under the soybean plant rows and five in the middle of the inter-rows $(0.20 \mathrm{~m}$ from the plant row) of each plot. The subsamples (within rows and between rows) were combined into a composite sample. The root samples were washed with tap water through a $0.5-\mathrm{mm}$ mesh sieve to avoid the excessive loss of material; the debris was removed by hand. Then, the roots were immersed in a $30 \%$ ethyl alcohol solution in plastic pots with lids and stored under refrigeration at $2{ }^{\circ} \mathrm{C}$ until evaluation. To evalu- 
Table 2

Probabilities of the calculated $F$-value for soil chemical properties at the depths of $0-0.05,0.05-0.10,0.10-0.20,0.20-0.40$ and $0.40-0.60 \mathrm{~m}$ at 48 and 60 months after reapplication of lime and phosphogypsum.

\begin{tabular}{|c|c|c|c|c|c|c|c|c|c|c|c|}
\hline \multirow[t]{2}{*}{ Depth (m) } & \multirow[t]{2}{*}{$F$-value } & \multicolumn{2}{|c|}{$\mathrm{pH}\left(\mathrm{CaCl}_{2}\right)$} & \multicolumn{2}{|l|}{$\mathrm{H}+\mathrm{Al}$} & \multicolumn{2}{|l|}{$\mathrm{Al}^{3+}$} & \multicolumn{2}{|l|}{ O.M. } & \multicolumn{2}{|l|}{$\mathrm{S}-\mathrm{SO}_{4}{ }^{2-}$} \\
\hline & & 48 & 60 & 48 & 60 & 48 & 60 & 48 & 60 & 48 & 60 \\
\hline $0-0.05$ & $\begin{array}{l}\text { Block } \\
\text { Treatment }\end{array}$ & $\begin{array}{r}0.140 \\
<0.001\end{array}$ & $\begin{array}{r}0.313 \\
<0.001\end{array}$ & $\begin{array}{r}0.110 \\
<0.001\end{array}$ & $\begin{array}{r}0.223 \\
<0.001\end{array}$ & $\begin{array}{r}0.968 \\
<0.001\end{array}$ & $\begin{array}{r}0.587 \\
<0.001\end{array}$ & $\begin{array}{r}0.233 \\
<0.001\end{array}$ & $\begin{array}{r}0.999 \\
<0.001\end{array}$ & $\begin{array}{r}0.187 \\
<0.001\end{array}$ & $\begin{array}{l}0.502 \\
0.028\end{array}$ \\
\hline $0.05-0.10$ & $\begin{array}{l}\text { Block } \\
\text { Treatment }\end{array}$ & $\begin{array}{r}0.284 \\
<0.001\end{array}$ & $\begin{array}{r}0.087 \\
<0.001\end{array}$ & $\begin{array}{r}0.120 \\
<0.001\end{array}$ & $\begin{array}{r}0.634 \\
<0.001\end{array}$ & $\begin{array}{r}0.118 \\
<0.001\end{array}$ & $\begin{array}{r}0.312 \\
<0.001\end{array}$ & $\begin{array}{r}0.809 \\
<0.001\end{array}$ & $\begin{array}{r}0.927 \\
<0.001\end{array}$ & $\begin{array}{l}0.089 \\
0.167\end{array}$ & $\begin{array}{l}0.992 \\
0.042\end{array}$ \\
\hline $0.10-0.20$ & $\begin{array}{l}\text { Block } \\
\text { Treatment }\end{array}$ & $\begin{array}{r}0.106 \\
<0.001\end{array}$ & $\begin{array}{l}0.247 \\
0.199\end{array}$ & $\begin{array}{r}0.101 \\
<0.001\end{array}$ & $\begin{array}{l}0.979 \\
0.037\end{array}$ & $\begin{array}{r}0.157 \\
<0.001\end{array}$ & $\begin{array}{r}0.389 \\
<0.001\end{array}$ & $\begin{array}{r}0.586 \\
<0.001\end{array}$ & $\begin{array}{r}0.929 \\
<0.001\end{array}$ & $\begin{array}{r}0.121 \\
<0.001\end{array}$ & $\begin{array}{l}0.134 \\
0.033\end{array}$ \\
\hline $0.20-0.40$ & $\begin{array}{l}\text { Block } \\
\text { Treatment }\end{array}$ & $\begin{array}{l}0.311 \\
0.198\end{array}$ & $\begin{array}{l}0.764 \\
0.003\end{array}$ & $\begin{array}{r}0.434 \\
<0.001\end{array}$ & $\begin{array}{l}0.070 \\
0.663\end{array}$ & $\begin{array}{l}0.097 \\
0.054\end{array}$ & $\begin{array}{r}0.095 \\
<0.001\end{array}$ & $\begin{array}{r}0.087 \\
<0.001\end{array}$ & $\begin{array}{r}0.672 \\
<0.001\end{array}$ & $\begin{array}{r}0.735 \\
<0.001\end{array}$ & $\begin{array}{l}0.589 \\
0.028\end{array}$ \\
\hline $0.40-0.60$ & $\begin{array}{l}\text { Block } \\
\text { Treatment }\end{array}$ & $\begin{array}{l}0.897 \\
0.238\end{array}$ & $\begin{array}{l}0.186 \\
0.026\end{array}$ & $\begin{array}{l}0.469 \\
0.034\end{array}$ & $\begin{array}{l}0.120 \\
0.325\end{array}$ & $\begin{array}{l}0.103 \\
0.073\end{array}$ & $\begin{array}{l}0.101 \\
0.850\end{array}$ & $\begin{array}{l}1.000 \\
0.053\end{array}$ & $\begin{array}{l}0.107 \\
0.542\end{array}$ & $\begin{array}{r}0.991 \\
<0.001\end{array}$ & $\begin{array}{l}0.127 \\
0.005\end{array}$ \\
\hline \multirow[t]{2}{*}{ Depth (m) } & $F$-value & \multicolumn{2}{|c|}{$\mathrm{P}($ resin $)$} & \multicolumn{2}{|c|}{$\mathrm{K}^{+}$} & \multicolumn{2}{|l|}{$\mathrm{Ca}^{2+}$} & \multicolumn{2}{|l|}{$\mathrm{Mg}^{2+}$} & \multicolumn{2}{|l|}{ V\% } \\
\hline & & 48 & 60 & 48 & 60 & 48 & 60 & 48 & 60 & 48 & 60 \\
\hline $0-0.05$ & $\begin{array}{l}\text { Block } \\
\text { Treatment }\end{array}$ & $\begin{array}{r}0.994 \\
<0.001\end{array}$ & $\begin{array}{r}0.499 \\
<0.001\end{array}$ & $\begin{array}{l}0.115 \\
0.214\end{array}$ & $\begin{array}{r}0.188 \\
<0.001\end{array}$ & $\begin{array}{r}0.506 \\
<0.001\end{array}$ & $\begin{array}{r}0.306 \\
<0.001\end{array}$ & $\begin{array}{r}0.353 \\
<0.001\end{array}$ & $\begin{array}{r}0.069 \\
<0.001\end{array}$ & $\begin{array}{r}0.299 \\
<0.001\end{array}$ & $\begin{array}{r}0.745 \\
<0.001\end{array}$ \\
\hline $0.05-0.10$ & $\begin{array}{l}\text { Block } \\
\text { Treatment }\end{array}$ & $\begin{array}{r}0.110 \\
<0.001\end{array}$ & $\begin{array}{r}0.212 \\
<0.001\end{array}$ & $\begin{array}{r}0.999 \\
<0.001\end{array}$ & $\begin{array}{l}0.999 \\
0.001\end{array}$ & $\begin{array}{r}0.107 \\
<0.001\end{array}$ & $\begin{array}{r}0.255 \\
<0.001\end{array}$ & $\begin{array}{r}0.125 \\
<0.001\end{array}$ & $\begin{array}{r}0.133 \\
<0.001\end{array}$ & $\begin{array}{r}0.101 \\
<0.001\end{array}$ & $\begin{array}{r}0.999 \\
<0.001\end{array}$ \\
\hline $0.10-0.20$ & $\begin{array}{l}\text { Block } \\
\text { Treatment }\end{array}$ & $\begin{array}{r}0.076 \\
<0.001\end{array}$ & $\begin{array}{r}0.413 \\
<0.001\end{array}$ & $\begin{array}{r}0.595 \\
<0.001\end{array}$ & $\begin{array}{r}0.512 \\
<0.001\end{array}$ & $\begin{array}{r}0.255 \\
<0.001\end{array}$ & $\begin{array}{r}0.718 \\
<0.001\end{array}$ & $\begin{array}{r}0.832 \\
<0.001\end{array}$ & $\begin{array}{r}0.791 \\
<0.001\end{array}$ & $\begin{array}{r}0.124 \\
<0.001\end{array}$ & $\begin{array}{r}0.855 \\
<0.001\end{array}$ \\
\hline $0.20-0.40$ & $\begin{array}{l}\text { Block } \\
\text { Treatment }\end{array}$ & $\begin{array}{l}0.243 \\
0.102\end{array}$ & $\begin{array}{l}0.481 \\
0.118\end{array}$ & $\begin{array}{l}0.249 \\
0.103\end{array}$ & $\begin{array}{l}0.950 \\
0.100\end{array}$ & $\begin{array}{r}0.821 \\
<0.001\end{array}$ & $\begin{array}{r}0.102 \\
<0.001\end{array}$ & $\begin{array}{r}0.859 \\
<0.001\end{array}$ & $\begin{array}{r}0.769 \\
<0.001\end{array}$ & $\begin{array}{r}0.137 \\
<0.001\end{array}$ & $\begin{array}{r}0.088 \\
<0.001\end{array}$ \\
\hline $0.40-0.60$ & $\begin{array}{l}\text { Block } \\
\text { Treatment }\end{array}$ & $\begin{array}{l}0.219 \\
0.207\end{array}$ & $\begin{array}{l}0.978 \\
0.159\end{array}$ & $\begin{array}{l}0.993 \\
0.200\end{array}$ & $\begin{array}{l}0.404 \\
0.159\end{array}$ & $\begin{array}{r}0.989 \\
<0.001\end{array}$ & $\begin{array}{r}0.418 \\
<0.001\end{array}$ & $\begin{array}{r}0.116 \\
<0.001\end{array}$ & $\begin{array}{r}0.203 \\
<0.001\end{array}$ & $\begin{array}{r}0.482 \\
<0.001\end{array}$ & $\begin{array}{r}0.111 \\
<0.001\end{array}$ \\
\hline
\end{tabular}


ate the root length density $\left(\mathrm{km} \mathrm{m}^{-3}\right)$ and diameter $(\mathrm{cm})$, the roots were digitalized using an optical scanner (Scanjet 4C/T, HP-USA, Palo Alto, CA) with a resolution of $250 \mathrm{dpi}$ and analysed using "Win Rhizo" version 3.8-b (Regent Instrument Inc., Quebec, Canada).

\subsection{Sampling and tissues analyses}

Soybean, black oat and sorghum leaf sampling for nutrient concentration analysis was performed when $50 \%$ of the plants were in the full flowering stage. The sampling was randomized by choosing 30 plants per plot and sampling the 3 rd leaf with the petiole for soybean (Ambrosano et al., 1997), the fourth leaf sheath visible counted from the apex for sorghum, and the flag leaf for black oat (Cantarella et al., 1997). At this stage, ten plants were sampled to determine the dry matter, which was expressed in $\mathrm{kg} \mathrm{ha}^{-1}$. The plant and leaf samples were dried by forced-air circulation at $65^{\circ} \mathrm{C}$ for $72 \mathrm{~h}$, and then the leaves were ground. The concentrations of $\mathrm{N}, \mathrm{P}, \mathrm{K}, \mathrm{Ca}, \mathrm{Mg}$, $\mathrm{S}, \mathrm{Cu}, \mathrm{Zn}, \mathrm{Fe}$ and $\mathrm{Mn}$ in the leaves were determined according to the methods described by Malavolta et al. (1997). Nitrogen was digested with $\mathrm{H}_{2} \mathrm{SO}_{4}$, and the other nutrients were digested with a nitro-perchloric solution. From the digested solution, N, P and S were determined by the Kjeldahl distillation, colorimetry and turbidimetry methods, respectively, and, $\mathrm{K}, \mathrm{Ca}, \mathrm{Mg}, \mathrm{Cu}, \mathrm{Zn}, \mathrm{Fe}$ and $\mathrm{Mn}$ were determined by atomic absorption spectrophotometry.

\subsection{Statistical analysis}

For all of the data, a two-way ANOVA was run using the statistical software package SISVAR (UFLA-Lavras, Minas Gerais, Brazil) (Ferreira, 2008). The blocks and all of the block interactions were considered random effects. The treatments and growing seasons were considered fixed effects. For the significant effects, the means were separated using Fisher's protected LSD test. For the soil chemical characteristics, nutrient, aboveground biomass, yield components and grain yield data, the effects were considered significant at $P \leq 0.05$, whereas the effects were considered significant at $P \leq 0.10$ for the root characteristic data. According to Gregory (2006), 15-20 root samples are necessary to detect significant differences at the $10 \%$ level of probability, whereas significance at the 5\% level often requires approximately 60-90 samples in each experimental unit. Therefore, a higher probability for the root system evaluation was used because these characteristics are more variable (Fageria and Moreira, 2011).

\section{Results}

\subsection{Soil chemical properties}

Surface liming increased the soil $\mathrm{pH}$ in the surface layers after 48 months to a depth of $0.20 \mathrm{~m}$, extending throughout the soil profile after 60 months of reapplication (Table 2 and Fig. 2). Phosphogypsum also influenced the soil $\mathrm{pH}$, with higher values than the control, reaching the same depths as observed with liming.

After 48 months, liming reduced the $\mathrm{H}+\mathrm{Al}$ contents to a depth of $0.60 \mathrm{~m}$, and after 60 months, $\mathrm{H}+\mathrm{Al}$ was restricted to a depth of $0-0.20 \mathrm{~m}$ (Table 2 and Fig. 2). The phosphogypsum also reduced the $\mathrm{H}+\mathrm{Al}$ contents compared to the control to a depth of $0.10 \mathrm{~m}$ at 48 months and persisted until 60 months after reapplication. $\mathrm{Al}^{3+}$ levels were reduced to a depth of $0.40 \mathrm{~m}$ with liming and phosphogypsum after 48 months and persisted until 60 months after reapplication (Table 2 and Fig. 2).

Phosphogypsum when applied with liming contributed little to improving the soil acidity components in the long term. With respect to soil acidity, 60 months after reapplication, there was

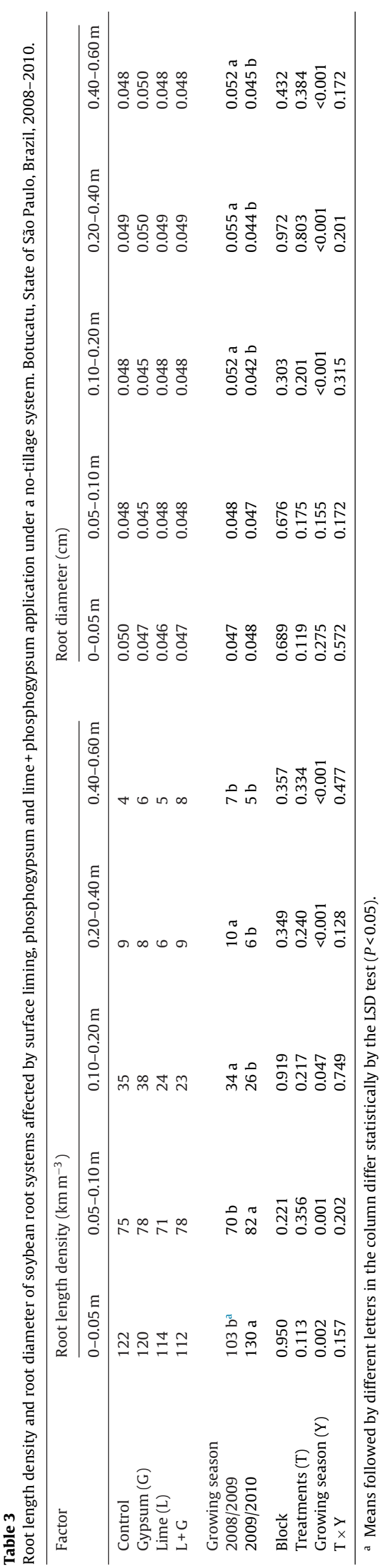


48 months

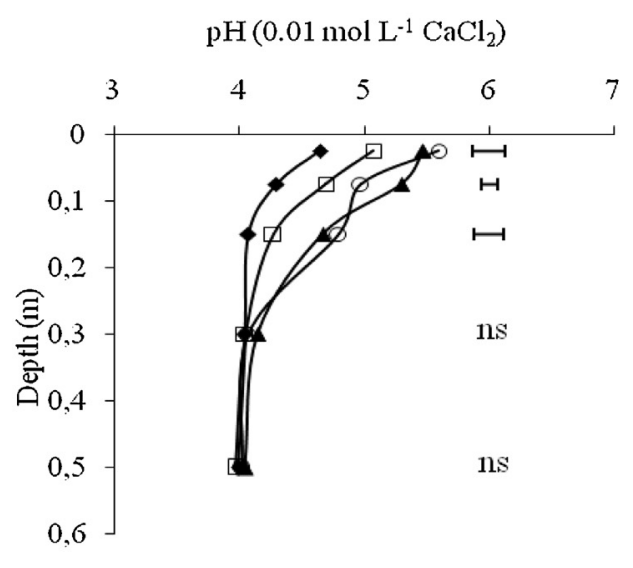

$\mathrm{H}+\mathrm{Al}\left(\mathrm{mmol}_{\mathrm{c}} \mathrm{kg}^{-1}\right)$

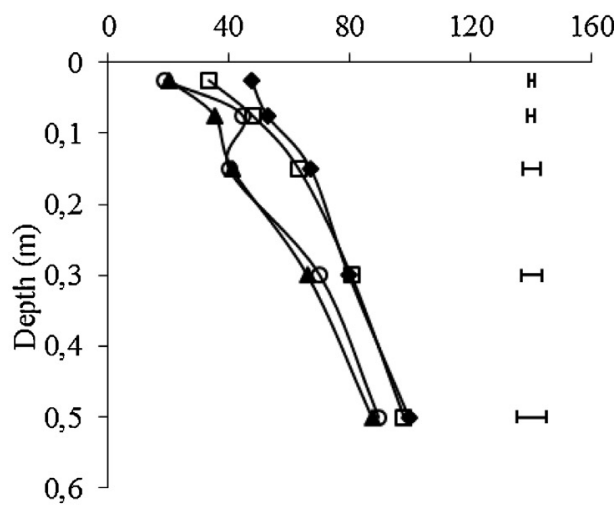

$\mathrm{Al}^{-3}\left(\mathrm{mmol}_{\mathrm{c}} \mathrm{kg}^{-1}\right)$

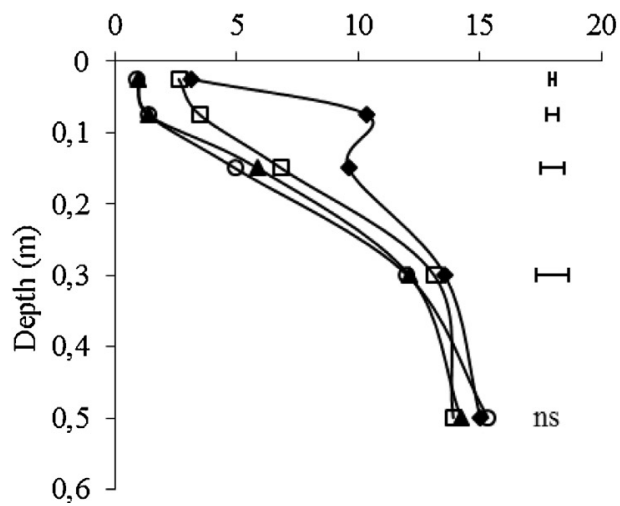

60 months

$\mathrm{pH}\left(0.01 \mathrm{~mol} \mathrm{~L}^{-1} \mathrm{CaCl}_{2}\right)$

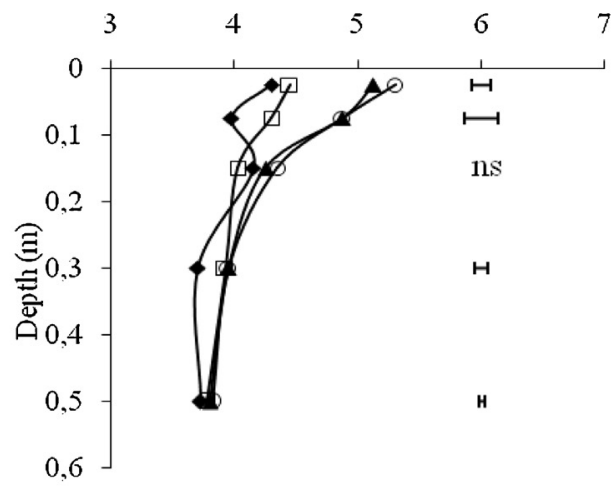

$\mathrm{H}+\mathrm{Al}\left(\mathrm{mmol}_{\mathrm{c}} \mathrm{kg}^{-1}\right)$

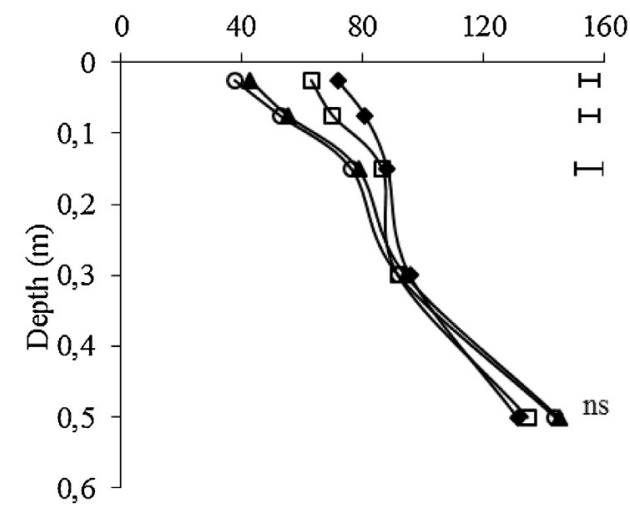

$\mathrm{Al}^{+3}\left(\mathrm{mmol}_{\mathrm{c}} \mathrm{kg}^{-1}\right)$

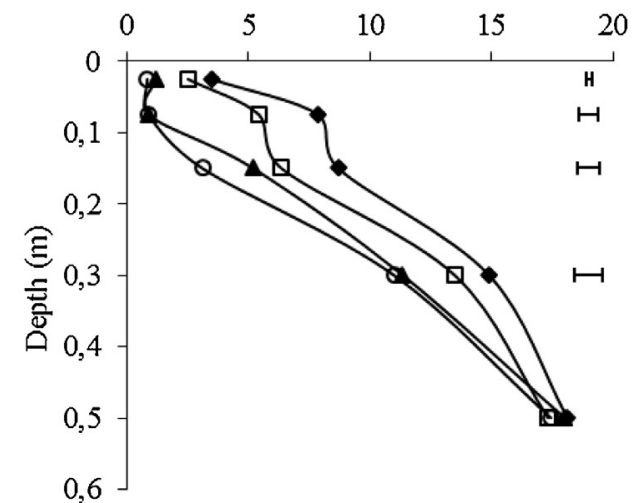

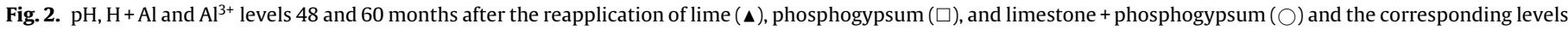
of the control $(\bullet)$. Horizontal bars indicate the least significant difference (LSD).

amelioration in the components of acidity, indicating that most of the applied products had already reacted.

The soil organic matter increased with liming (Table 2 and Fig. 3) throughout the soil profile 48 months after reapplication, and this effect was observed up to $0.40 \mathrm{~m} 60$ months after reapplication. Liming, when associated with phosphogypsum, provided the highest levels in the deeper layers $(0.20-0.60 \mathrm{~m})$ after 48 months; after 60 months, it provided the highest levels only in the 0.05-0.10$\mathrm{m}$ and $0.20-0.40-\mathrm{m}$ layers. The effects of phosphogypsum were only observed after 60 months at depths of $0-0.05$ and $0.20-0.40 \mathrm{~m}$ compared to the control.
The $\mathrm{S}_{-} \mathrm{SO}_{4}{ }^{2-}$ levels increased in the soil layers of $0.10-0.60 \mathrm{~m}$ with phosphogypsum application, with or without liming, after 48 months (Table 2 and Fig. 3). After 60 months, this effect was extended to the layer of $0.05-0.60 \mathrm{~m}$. In the most superficial layer of the soil ( $0-0.05 \mathrm{~m})$, only an effect of phosphogypsum was observed.

Liming after 48 months increased $\mathrm{K}$ levels at a depth of 0.05-0.20 $\mathrm{m}$ and $\mathrm{P}$ at a depth of $0-0.20 \mathrm{~m}$, and when associated with phosphogypsum, the P levels were even higher in the layer from 0 to $0.10 \mathrm{~m}$ (Table 2 and Fig. 4). After 60 months, the effects of lime, with or without phosphogypsum, on $\mathrm{K}$ levels were observed at a depth 
48 months

O.M. $\left(\mathrm{g} \mathrm{kg}^{-1}\right)$

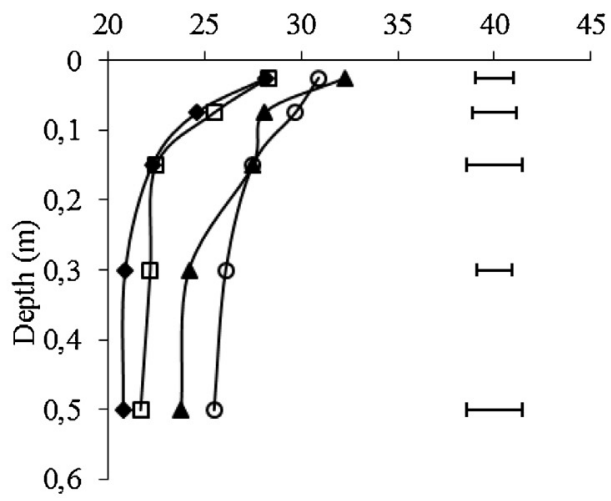

$\mathrm{S}-\mathrm{SO}_{4}^{-2}\left(\mathrm{mg} \mathrm{kg}^{-1}\right)$

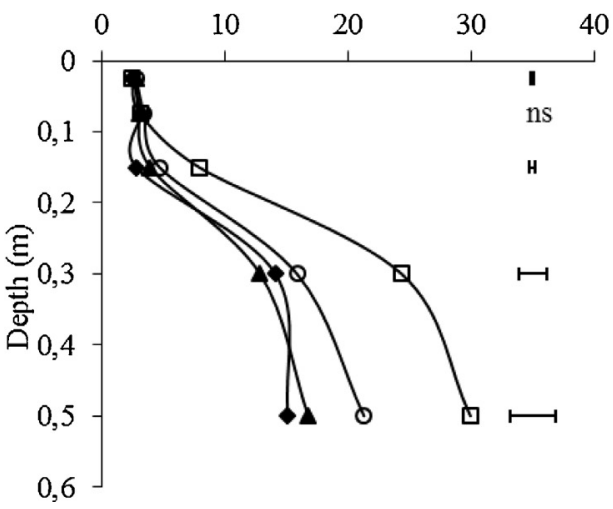

60 months

O.M. (g kg-1)

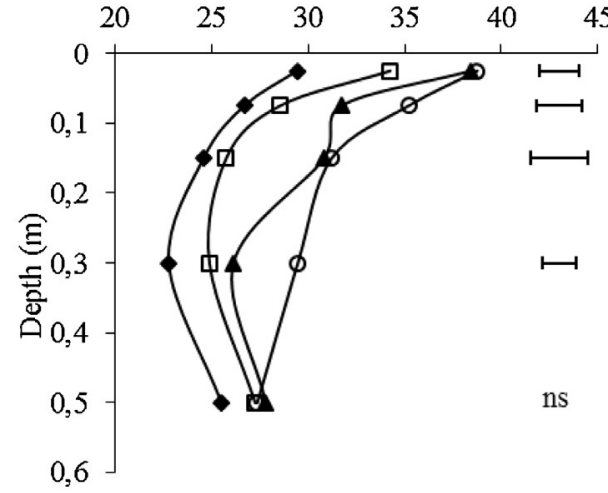

$\mathrm{S}^{-\mathrm{SO}_{4}}{ }^{-2}\left(\mathrm{mg} \mathrm{kg}^{-1}\right)$

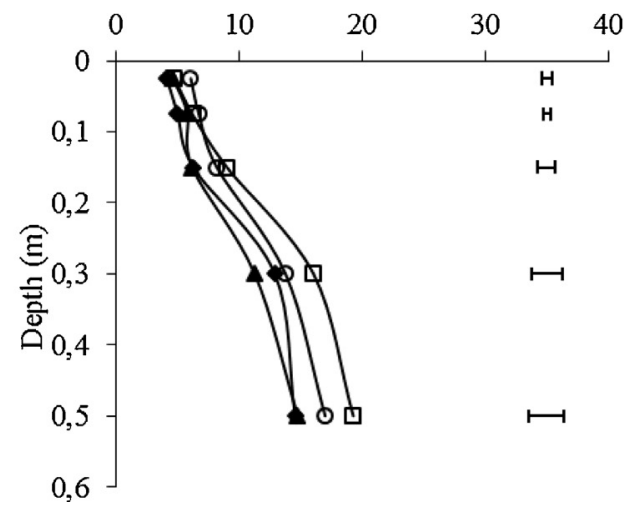

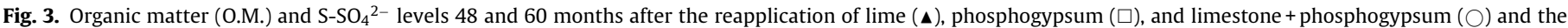
corresponding levels of the control $(\downarrow)$. Horizontal bars indicate the least significant difference (LSD).

of 0-0.05 m. However, phosphogypsum application associated with lime no longer changed the P levels after 60 months.

After 48 to 60 months, the $\mathrm{Ca}^{2+}$ and $\mathrm{Mg}^{2+}$ levels increased at all depths with liming (Table 2 and Fig. 5). However, when combined with phosphogypsum, the concentrations of $\mathrm{Ca}^{2+}$ increased throughout the soil profile except in the layer from 0.05 to $0.10 \mathrm{~m}$ after 60 months, whereas the $\mathrm{Mg}^{2+}$ levels decreased at depths of $0.10-0.20$ and $0.40-0.60 \mathrm{~m}$ after 48 months and in the layer from 0.05 to $0.60 \mathrm{~m}$ after 60 months. Phosphogypsum also positively influenced the $\mathrm{Ca}^{2+}$ levels at all of the depths compared with the control but reduced the $\mathrm{Mg}^{2+}$ levels at depths of $0.10-0.20$ and $0.20-0.40 \mathrm{~m}$ after 48 and 60 months, respectively.

The soil amendment effects on the $\mathrm{H}+\mathrm{Al}$ contents, $\mathrm{Ca}$ and $\mathrm{Mg}$ were reflected in the base saturation (Table 2 and Fig. 5). Liming and phosphogypsum increased the base saturation throughout the soil profile after 48 and 60 months.

\subsection{Soybean root growth}

The soybean root characteristics were influenced only by the year effect, with no significant interaction (Table 3). Thus, phosphogypsum and lime application did not alter the length or average diameter of the soybean roots. Regarding the year effect, the root growth at the soil surface $(0-0.10 \mathrm{~m})$ was higher in 2009/2010, with approximately $85 \%$ of the roots found in this layer at this time, whereas in 2008/2009, this proportion was $77 \%$. However, below a depth of $0.10 \mathrm{~m}$, the highest growth and root diameter were observed in 2008/09.

\subsection{Nutrition and grain yield}

There was no significant interaction between the treatments and year for any evaluated nutrient (Table 4). The P and Fe concentrations in the soybean leaves were not influenced by the treatments, nor were the $\mathrm{P}, \mathrm{Ca}, \mathrm{Cu}$ and $\mathrm{Mn}$ concentrations influenced by the year. The $\mathrm{N}, \mathrm{Ca}, \mathrm{Mg}$ and $\mathrm{S}$ concentrations increased with liming and were even higher when associated with phosphogypsum with the exception of Mg. However, the micronutrient concentrations ( $\mathrm{Cu}, \mathrm{Zn}$ and $\mathrm{Mn}$ ) were inversely proportional to the macronutrient concentrations. Regarding the effect of year, the highest concentrations of $\mathrm{N}, \mathrm{K}, \mathrm{Mg}, \mathrm{S}, \mathrm{Cu}, \mathrm{Zn}$ and Fe were found in $2008 / 2009$.

The yield components and shoot dry matter of soybean were influenced by the effects of the treatments and year; however, there were no significant interactions (Table 4). The surface application of lime increased the shoot dry matter, plant population and the 100 -grain weight, and when associated with phosphogypsum, the number of pods per plant was higher, directly reflecting the grain yield. The application of limestone alone and in association with phosphogypsum increased the grain yield by 17 and 29\%, respectively. In 2008/2009, the production of shoot dry matter, plant population and 100-grain weight were higher; however, the aver- 
Table 4

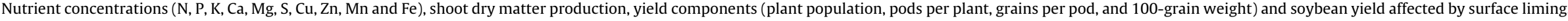
phosphogypsum and lime + phosphogypsum application under a no-tillage system. Botucatu, State of São Paulo, Brazil, 2008-2010.

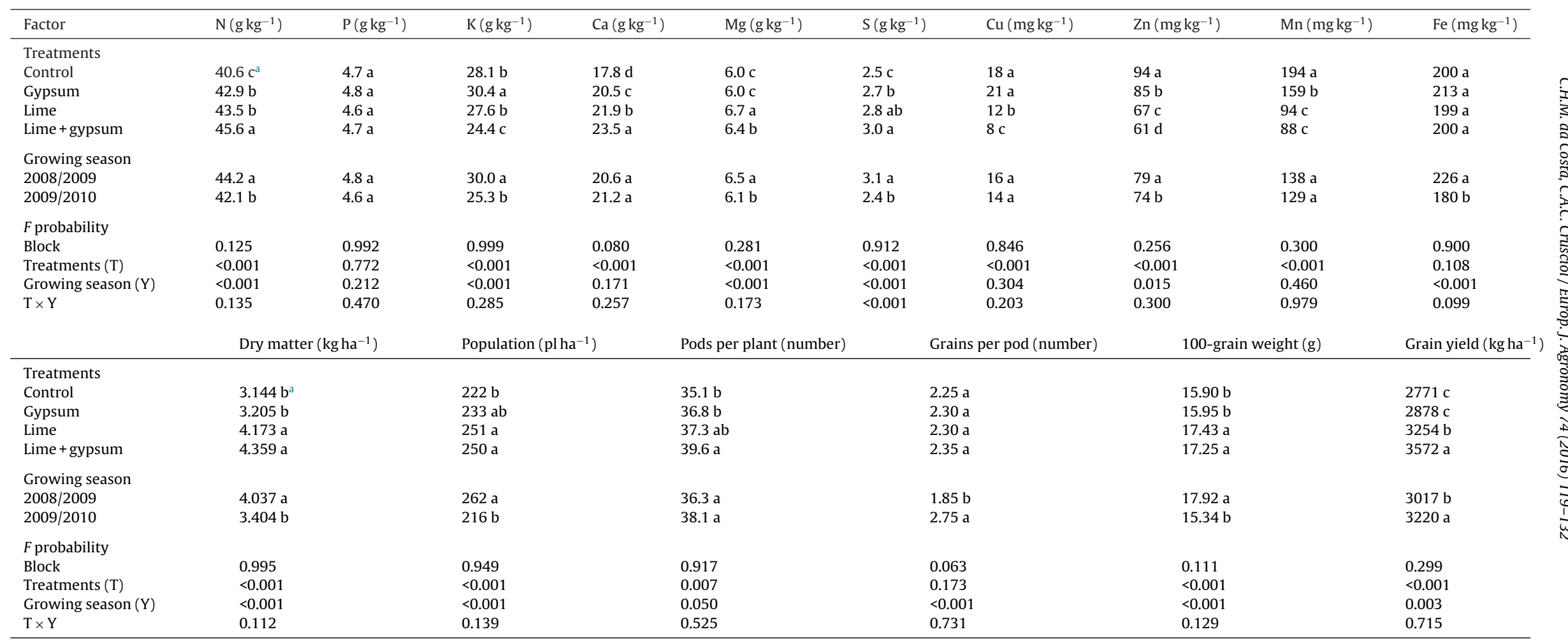

a Means followed by different letters in the column differ statistically by the LSD test $(P<0.05)$. 
48 months

$\mathrm{P}$ (resin $\mathrm{mg} \mathrm{kg}^{-1}$ )

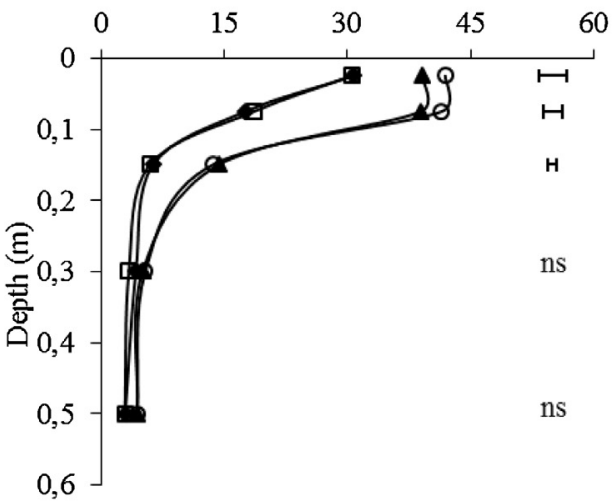

$\mathrm{K}^{\div}\left(\mathrm{mmol}_{\mathrm{c}} \mathrm{kg}^{-1}\right)$

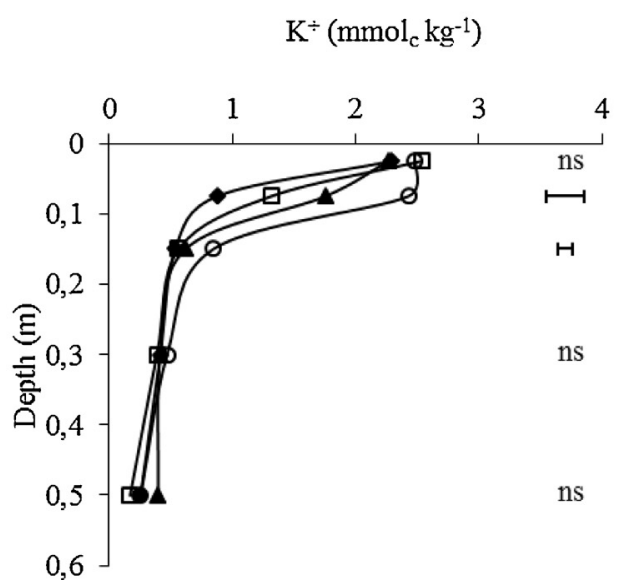

60 months

$\mathrm{P}\left(\right.$ resin $\left.\mathrm{mg} \mathrm{kg}^{-1}\right)$
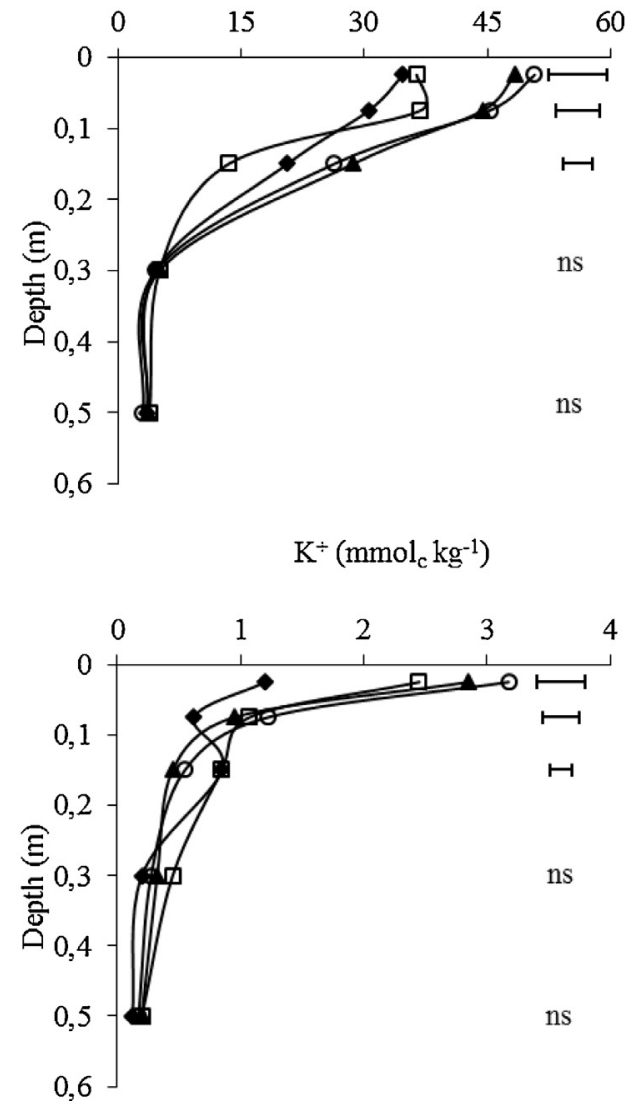

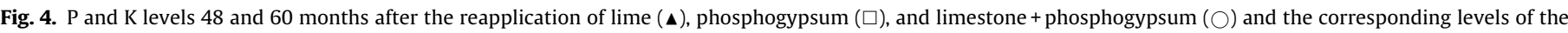
control ( $)$. Horizontal bars indicate the least significant difference (LSD).

age number of grains per pod was higher in 2009/2010 and reflected the higher grain yield this season.

In the black oat crop, the $\mathrm{N}, \mathrm{P}, \mathrm{K}, \mathrm{Cu}$ and $\mathrm{Zn}$ concentrations were not affected by product application (Table 5). However, the Ca concentration increased with product application, with the highest concentrations observed with liming. The $\mathrm{Mg}$ concentration increased only with liming, whereas that of S increased with phosphogypsum application, with or without liming. The $\mathrm{Mn}$ and Fe concentrations decreased with liming, and the decrease in Mn was greater when liming was associated with phosphogypsum.

Regarding the shoot dry matter and yield components of black oat, liming increased the shoot dry matter and number of panicles per $\mathrm{m}^{2}$ (Table 5). However, the number of panicles per $\mathrm{m}^{2}$ was lower when liming was combined with phosphogypsum, reducing the yield by $6 \%$; however, compared with the control, the yields with lime alone and lime associated with phosphogypsum were higher, at 54 and $44 \%$, respectively.

Liming increased the uptake of $\mathrm{N}, \mathrm{Ca}, \mathrm{Mg}$ and $\mathrm{S}$ by sorghum and that of Ca was greater when liming was combined with phosphogypsum (Table 6). Phosphogypsum application only influenced the absorption of S compared to that of the control. Regarding micronutrients, liming, with or without phosphogypsum only reduced the uptake of Mn.

The shoot dry matter, number of panicles per $\mathrm{m}^{2}$, and number of grains per panicle of sorghum were influenced by lime and phosphogypsum application, which was reflected directly in the grain yield (Table 6). Thus, the grain yield with the application of phosphogypsum, limestone and limestone associated with phosphogypsum was 191,1406 and $1589 \mathrm{~kg} \mathrm{ha}^{-1}$ higher, respectively, than that of the control. We note that each crop has a different response to soil amendments, which may be related to intrinsic characteristics, such as the weather conditions during development.

\section{Discussion}

\subsection{Soil chemical properties}

Surface lime application corrected the soil acidity in the soil profile (Fig. 2). Caires et al. (2005) and Caires et al. (2011) found that surface lime application under no-till in southern Brazil, a subtropical region, reduced the soil acidity in the long term throughout the soil profile after 120 months in a loamy Typic Hapludox $(0-0.20 \mathrm{~m})$ and after 84 months in a clayey Rhodic Hapludox $(0-0.60 \mathrm{~m})$, respectively. Acidity correction occurs with an increase in the concentration of hydroxyl, a limestone dissociation product in the soil, as a fraction of this hydroxyl group reacts with excess $\mathrm{H}^{+}$in the solution, reducing the concentration of $\mathrm{H}+\mathrm{Al}$ and increasing the soil $\mathrm{pH}$, while the remainder promotes aluminium precipitation in the form of $\mathrm{Al}(\mathrm{OH})_{3}$, an element which is not toxic to plants (de Oliveira and Pavan, 1996). Thus, subsoil correction can occur due to several factors, such as the physical displacement of the fine particles of limestone through the water movement via channels that are formed by dead roots and organisms (de Oliveira and Pavan, 1996; Rheinheimer et al., 2000) and through weakness planes (Amaral et al., 2004), which are kept intact due the minimum soil disturbance in a no-till system. Another factor that can be attributed to 
48 months

$\mathrm{Ca}^{+2}\left(\mathrm{mmol}_{\mathrm{c}} \mathrm{kg}^{-1}\right)$

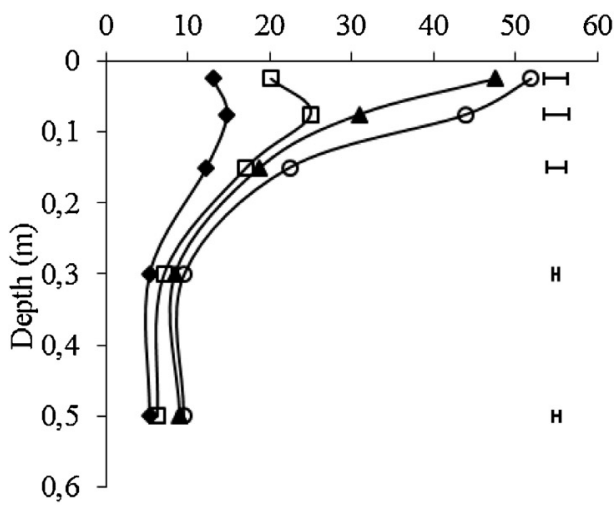

$\mathrm{Mg}^{\circ 2}\left(\mathrm{mmol}_{\mathrm{c}} \mathrm{kg}^{-1}\right)$

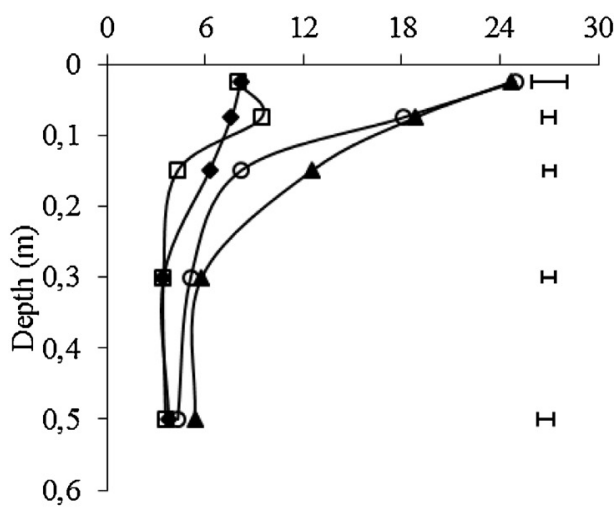

B.S. (\%)

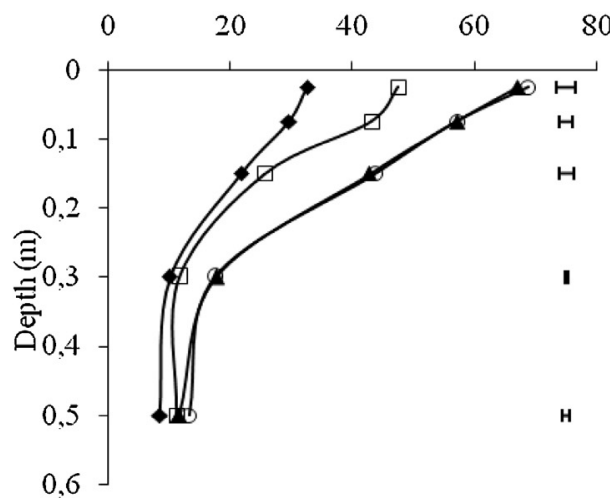

60 months

$\mathrm{Ca}^{-2}\left(\mathrm{mmol}_{\mathrm{c}} \mathrm{kg}^{-1}\right)$

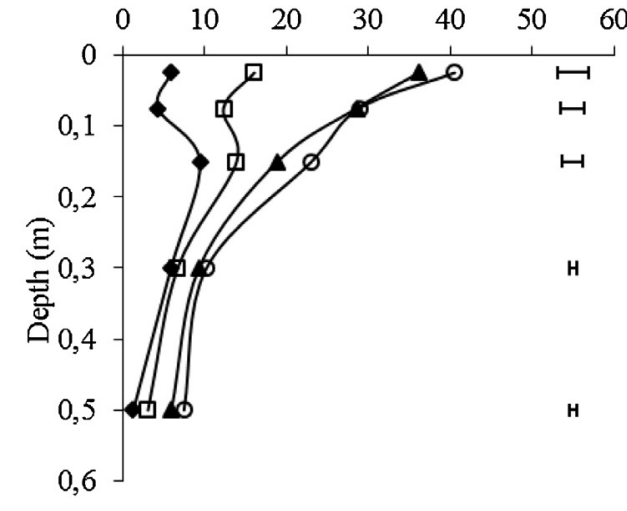

$\mathrm{Mg}^{2}\left(\mathrm{mmol}_{\mathrm{c}} \mathrm{kg}^{-1}\right)$

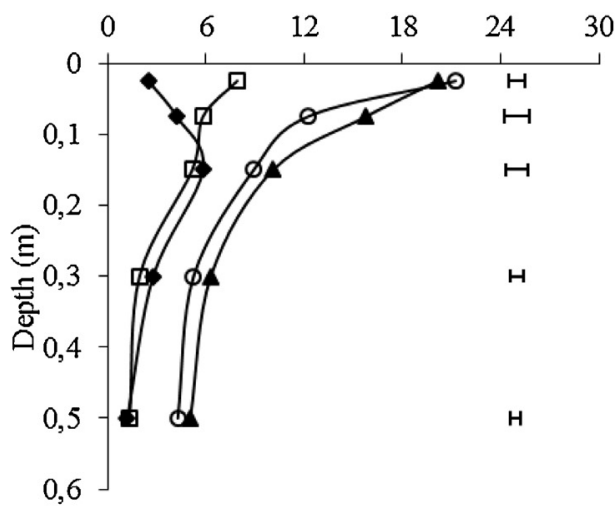

B.S. (\%)

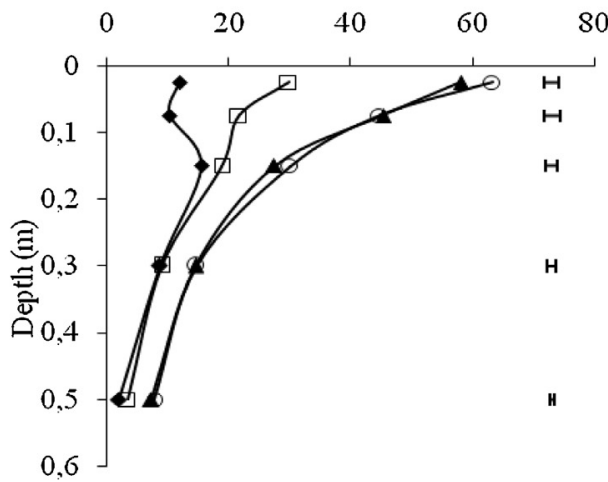

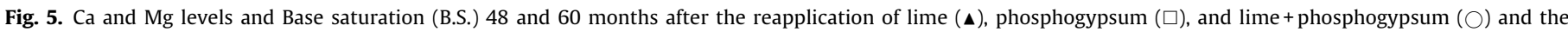
corresponding levels of the control $(\downarrow)$. Horizontal bars indicate the least significant difference (LSD).

the effect of surface liming in the subsoil is the movement of ions. The increased soil $\mathrm{pH}$ on the soil surface due to superficial application can accelerate the rate at which $\mathrm{HCO}_{3}{ }^{-}$ions, followed by $\mathrm{Ca}$ and $\mathrm{Mg}$, move into the subsoil to react to acidity (Caires et al., 2003). According to Rheinheimer et al. (2000), the effects of liming at depth only occurred when the $\mathrm{pH}$ in the water in the limestone dissolution zone was between 5.2 and 5.6. In this situation, the formation and migration of $\mathrm{Ca}\left(\mathrm{HCO}_{3}\right)_{2}$ and $\mathrm{Mg}\left(\mathrm{HCO}_{3}\right)_{2}$ occurred in the subsurface layers. This effect with depth is known as the "alkalizing front", as noted by several authors (Caires et al., 2008c; Soratto and Crusciol, 2008b).
Surface phosphogypsum application, compared to the control, influenced the soil acidity components (Fig. 2). Caires et al. (2003) observed an increase in the soil pH in the layers of $0.20-0.40$ (8 months) and $0.40-0.60 \mathrm{~m}$ (8, 20 and 32 months), and Soratto and Crusciol (2008b) reported a decrease in the exchangeable $\mathrm{Al}$ at all depths 12 months after application. These results have been attributed to an exchange reaction of ligands on the surface of soil particles involving hydrated oxides of iron and aluminium, with $\mathrm{SO}_{4}{ }^{2-}$ displacing $\mathrm{OH}^{-}$and thus promoting the partial neutralization of acidity (Reeve and Sumner, 1972). In addition, aluminium precipitation could also occur with the formation of minerals (Adams and Rawajfih, 1977). Another possibility is the leaching of 
Table 5

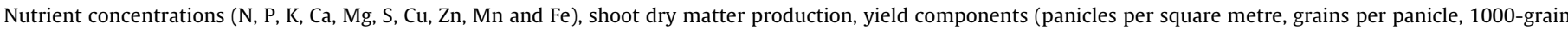

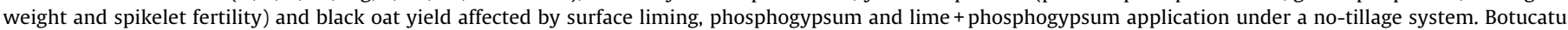
State of São Paulo, Brazil, 2008-2010.

\begin{tabular}{|c|c|c|c|c|c|c|c|c|c|c|c|c|}
\hline & $\mathrm{N}\left(\mathrm{g} \mathrm{kg}^{-1}\right)$ & $\mathrm{P}\left(\mathrm{g} \mathrm{kg}^{-1}\right)$ & $\mathrm{K}\left(\mathrm{g} \mathrm{kg}^{-1}\right)$ & \multicolumn{2}{|c|}{$\mathrm{Ca}\left(\mathrm{g} \mathrm{kg}^{-1}\right)$} & $\operatorname{Mg}\left(\mathrm{g} \mathrm{kg}^{-1}\right)$ & $\mathrm{S}\left(\mathrm{g} \mathrm{kg}^{-1}\right)$ & $\mathrm{Cu}\left(\mathrm{mg} \mathrm{kg}^{-1}\right)$ & $\mathrm{Zn}\left(\mathrm{mg} \mathrm{kg}^{-1}\right)$ & \multicolumn{2}{|c|}{$\operatorname{Mn}\left(\mathrm{mg} \mathrm{kg}^{-1}\right)$} & $\mathrm{Fe}\left(\mathrm{mg} \mathrm{kg}^{-1}\right)$ \\
\hline \multicolumn{13}{|l|}{ Treatments } \\
\hline Control & $19.7 a^{a}$ & $3.9 \mathrm{a}$ & 30.9 a & $10.6 \mathrm{c}$ & & $4.6 \mathrm{~b}$ & $2.5 \mathrm{bc}$ & $10.4 \mathrm{a}$ & $55 \mathrm{a}$ & $259 a$ & & $173 a$ \\
\hline Gypsum (G) & $20.5 \mathrm{a}$ & $3.9 \mathrm{a}$ & $28.3 \mathrm{a}$ & $11.6 \mathrm{~b}$ & & $4.7 \mathrm{~b}$ & $2.9 \mathrm{a}$ & $10.9 \mathrm{a}$ & $59 \mathrm{a}$ & $268 \mathrm{a}$ & & $177 \mathrm{a}$ \\
\hline Lime (L) & $19.4 \mathrm{a}$ & $3.9 \mathrm{a}$ & $29.5 \mathrm{a}$ & $13.0 \mathrm{a}$ & & $5.4 \mathrm{a}$ & $2.4 \mathrm{c}$ & $10.4 \mathrm{a}$ & $53 a$ & $195 \mathrm{~b}$ & & $115 \mathrm{~b}$ \\
\hline $\mathrm{L}+\mathrm{G}$ & $19.1 \mathrm{a}$ & $3.7 \mathrm{a}$ & $31.7 \mathrm{a}$ & $12.6 \mathrm{a}$ & & $4.9 \mathrm{~b}$ & $2.7 \mathrm{ab}$ & $10.9 \mathrm{a}$ & $50 a$ & $147 \mathrm{c}$ & & $124 \mathrm{~b}$ \\
\hline \multicolumn{13}{|l|}{$F$ probability } \\
\hline Block & 0.999 & 0.895 & 0.555 & 0.250 & & 0.431 & 0.362 & 0.146 & 0.136 & 0.354 & & 0.265 \\
\hline \multirow[t]{2}{*}{ Treatments } & 0.726 & 0.423 & 0.248 & $<0.001$ & & $<0.001$ & 0.007 & 0.889 & 0.159 & $<0.001$ & & 0.001 \\
\hline & \multicolumn{2}{|c|}{ Dry matter $\left(\mathrm{kg} \mathrm{ha}^{-1}\right)$} & \multicolumn{2}{|c|}{ Panicles $\mathrm{m}^{2}$ (number) } & \multicolumn{3}{|c|}{ Grains per panicle (number) } & 1000 -grain weight $(\mathrm{g})$ & \multicolumn{2}{|c|}{ Spikelet fertility (\%) } & \multicolumn{2}{|c|}{ Grain yield $\left(\mathrm{kg} \mathrm{ha}^{-1}\right)$} \\
\hline \multicolumn{13}{|l|}{ Treatments } \\
\hline Control & $4632 \mathrm{c}$ & & $138 \mathrm{c}$ & \multicolumn{3}{|c|}{$46 a$} & \multicolumn{2}{|r|}{$18.6 \mathrm{a}$} & $84 \mathrm{a}$ & \multicolumn{3}{|c|}{$960 \mathrm{c}$} \\
\hline Gypsum (G) & $4868 \mathrm{c}$ & & $147 \mathrm{c}$ & \multicolumn{3}{|c|}{$45 \mathrm{a}$} & \multicolumn{2}{|r|}{$18.9 \mathrm{a}$} & $83 a$ & \multicolumn{3}{|c|}{$1009 \mathrm{c}$} \\
\hline Lime (L) & 5856 a & & $216 a$ & \multicolumn{3}{|c|}{$46 a$} & \multicolumn{2}{|r|}{$19.1 \mathrm{a}$} & $80 \mathrm{a}$ & \multicolumn{3}{|c|}{$1476 \mathrm{a}$} \\
\hline $\mathrm{L}+\mathrm{G}$ & $5484 \mathrm{a}$ & & $205 b$ & \multicolumn{3}{|c|}{$45 \mathrm{a}$} & \multicolumn{2}{|r|}{$19.4 \mathrm{a}$} & $79 \mathrm{a}$ & \multicolumn{3}{|c|}{$1382 \mathrm{~b}$} \\
\hline \multicolumn{13}{|l|}{$F$ probability } \\
\hline Block & 0.215 & & 0.252 & \multicolumn{3}{|c|}{0.101} & \multicolumn{2}{|r|}{0.835} & 0.118 & & 0.22 & \\
\hline Treatments & $<0.001$ & & $<0.001$ & & 0.943 & & & 0.761 & 0.367 & & $<0.00$ & \\
\hline
\end{tabular}

a Means followed by different letters in the column differ statistically by the LSD test $(P<0.05)$.

Table 6

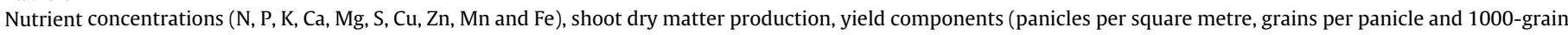

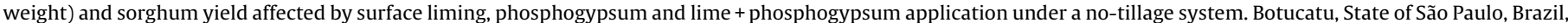
2008-2010.

\begin{tabular}{|c|c|c|c|c|c|c|c|c|c|c|}
\hline & $\mathrm{N}\left(\mathrm{g} \mathrm{kg}^{-1}\right)$ & $\mathrm{P}\left(\mathrm{g} \mathrm{kg}^{-1}\right)$ & $\mathrm{K}\left(\mathrm{g} \mathrm{kg}^{-1}\right)$ & $\mathrm{Ca}\left(\mathrm{g} \mathrm{kg}^{-1}\right)$ & $\mathrm{Mg}\left(\mathrm{g} \mathrm{kg}^{-1}\right)$ & $\mathrm{S}\left(\mathrm{g} \mathrm{kg}^{-1}\right)$ & $\mathrm{Cu}\left(\mathrm{mg} \mathrm{kg}^{-1}\right)$ & $\mathrm{Zn}\left(\mathrm{mg} \mathrm{kg}^{-1}\right)$ & $\mathrm{Mn}\left(\mathrm{mg} \mathrm{kg}^{-1}\right)$ & $\mathrm{Fe}\left(\mathrm{mg} \mathrm{kg}^{-1}\right)$ \\
\hline \multicolumn{11}{|l|}{ Treatments } \\
\hline Control & $27.2 \mathrm{~b}^{\mathrm{a}}$ & $3.9 \mathrm{a}$ & $18.0 \mathrm{a}$ & $9.4 \mathrm{c}$ & $3.8 \mathrm{~b}$ & $1.8 \mathrm{c}$ & $9.3 \mathrm{a}$ & $47 \mathrm{a}$ & $42 \mathrm{a}$ & $344 \mathrm{a}$ \\
\hline Gypsum (G) & $27.8 \mathrm{~b}$ & $4.0 \mathrm{a}$ & $17.6 \mathrm{a}$ & $10.1 \mathrm{c}$ & $3.9 \mathrm{~b}$ & $2.1 \mathrm{~b}$ & $8.8 \mathrm{a}$ & $45 \mathrm{a}$ & $39 \mathrm{a}$ & $323 a$ \\
\hline Lime (L) & $28.8 \mathrm{ab}$ & $4.0 \mathrm{a}$ & $17.9 \mathrm{a}$ & $11.2 \mathrm{~b}$ & $4.1 \mathrm{ab}$ & $2.7 \mathrm{a}$ & $6.8 \mathrm{a}$ & $43 a$ & $35 \mathrm{~b}$ & $314 a$ \\
\hline $\mathrm{L}+\mathrm{G}$ & $30.1 \mathrm{a}$ & $3.9 \mathrm{a}$ & $18.7 \mathrm{a}$ & $12.7 \mathrm{a}$ & $4.7 \mathrm{a}$ & $2.7 \mathrm{a}$ & $8.0 \mathrm{a}$ & $39 a$ & $32 \mathrm{~b}$ & $297 \mathrm{a}$ \\
\hline \multicolumn{11}{|l|}{$F$ probability } \\
\hline Block & 0.301 & 0.113 & 0.703 & 0.985 & 0.912 & 0.201 & 0.062 & 0.827 & 0.771 & 0.091 \\
\hline \multirow[t]{2}{*}{ Treatments } & 0.012 & 0.080 & 0.171 & $<0.001$ & 0.039 & $<0.001$ & 0.118 & 0.369 & $<0.001$ & 0.616 \\
\hline & \multicolumn{2}{|c|}{ Dry matter $\left(\mathrm{kg} \mathrm{ha}^{-1}\right)$} & \multicolumn{2}{|c|}{ Panicles $\mathrm{m}^{2}$ (number) } & \multicolumn{3}{|c|}{ Grains per panicle (number) } & 1000-grain weig & \multicolumn{2}{|c|}{ Grain yield $\left(\mathrm{kg} \mathrm{ha}^{-1}\right)$} \\
\hline \multicolumn{11}{|l|}{ Treatments } \\
\hline Control & \multicolumn{2}{|l|}{$1513 d$} & \multicolumn{2}{|l|}{$11.0 \mathrm{~d}$} & \multicolumn{2}{|l|}{$11 \mathrm{c}$} & \multicolumn{2}{|r|}{$36.6 \mathrm{a}$} & \multicolumn{2}{|l|}{$45 \mathrm{~d}$} \\
\hline Gypsum (G) & \multicolumn{2}{|l|}{$2307 \mathrm{c}$} & \multicolumn{2}{|l|}{$11.9 \mathrm{c}$} & \multicolumn{2}{|l|}{$57 \mathrm{~b}$} & \multicolumn{2}{|r|}{$34.1 \mathrm{a}$} & \multicolumn{2}{|c|}{$236 c$} \\
\hline Lime (L) & \multicolumn{2}{|l|}{$4084 \mathrm{~b}$} & \multicolumn{2}{|l|}{$17.2 \mathrm{~b}$} & \multicolumn{2}{|l|}{$245 a$} & \multicolumn{2}{|r|}{$34.7 \mathrm{a}$} & \multicolumn{2}{|c|}{$1451 \mathrm{~b}$} \\
\hline $\mathrm{L}+\mathrm{G}$ & \multicolumn{2}{|l|}{$6750 \mathrm{a}$} & \multicolumn{2}{|l|}{$18.5 \mathrm{a}$} & \multicolumn{2}{|l|}{$237 \mathrm{a}$} & \multicolumn{2}{|r|}{$35.6 \mathrm{a}$} & \multicolumn{2}{|c|}{$1634 \mathrm{a}$} \\
\hline \multicolumn{11}{|l|}{$F$ probability } \\
\hline Block & \multicolumn{2}{|l|}{0.156} & \multicolumn{2}{|l|}{0.899} & \multicolumn{2}{|l|}{0.391} & \multicolumn{2}{|r|}{0.923} & \multicolumn{2}{|c|}{0.185} \\
\hline Treatments & $<0.001$ & & $<0.00$ & & $<0.001$ & & & 0.257 & $<0.0$ & \\
\hline
\end{tabular}

a Means followed by different letters in the column differ statistically by the LSD test $(P<0.05)$.

$\mathrm{Al}$ accompanying phosphogypsum, which can be partly favoured by the formation, primarily, of ion pairs or complexes of $\mathrm{AlSO}_{4}{ }^{+}$ (Pavan et al., 1984).

In addition, in contrast to the previous soil evaluation, soil acidification occurred (Fig. 2). This effect may suggest that large amounts of lime have already reacted by 60 months because with the total reaction of lime, it is probable that the acidification processes manifest through the $\mathrm{pH}$ values, considering the soil buffering capacity, the nutrient extraction processes and the increase in the use of ammonium base nitrogen fertilizer (Caires et al., 2005; Juo et al., 1995). Ciotta et al. (2002) reported soil acidification in a no-till system and explained this effect by the ammonium nitrification process from the acid reaction of fertilizers, which concentrate on the soil surface.

The soil organic matter increased with liming after 48 and 60 months, with or without phosphogypsum (Fig. 3). However, the effects of phosphogypsum were only observed at 60 months. With liming, there is a pH elevation and a concomitant increase in micro- bial activity (Ekenler and Tabatabai, 2003). This increase accelerates the decomposition of soil organic matter and reduces the stock of soil C (Chan and Heenan, 1999). This effect tends to last only for the short term; however, long-term liming can promote the accumulation of organic matter (Briedis et al., 2012; Hati et al., 2008). This C accumulation in the long-term is related to a greater biomass production per area as a result of soil fertility improvements, such as increased $\mathrm{pH}$, the supply of $\mathrm{Ca}$ and $\mathrm{Mg}$, and $\mathrm{Al}^{3+}$ reduction. It should be taken into account that sixteen crops were grown in sequence in this area in the period between 2002 and 2009 with a significant accumulation of crop residues, including roots, whose development was also improved by soil amendment.

The sulphate levels were influenced only by the application of phosphogypsum, with or without liming, below the surface layer, with reduced levels observed during the study period (Fig. 3). Caires et al. (2006b), in a clayey Rhodic Hapludox, verified an increase in sulphate levels at depths of up to $0.80 \mathrm{~m}$ with superficial phosphogypsum application (3,6 and $9 \mathrm{tha}^{-1}$ ) after 53 months, but 
only a small fraction was retained in the layer of $0-0.20 \mathrm{~m}$, and the remainder leached into deeper layers. Caires et al. (2011), in a clayey Rhodic Hapludox, also found similar effects with superficial phosphogypsum application ( $9 \mathrm{Mg} \mathrm{ha}^{-1}$ ) after 84 months.

The small retention of sulphate in the upper soil layers is due to the higher $\mathrm{pH}$ values and organic matter levels in these layers. The increase in soil $\mathrm{pH}$ promotes a predominantly negative net charge, and the organic matter generates a large number of negative charges in the soil, favouring the movement of sulphate (Camargo and van Raij, 1989; Quaggio et al., 1993). In addition, the sulphate adsorbed on hydroxylated surfaces by specific adsorption decreases with increasing pH (Rietra et al., 1999).

Surface liming increased the $\mathrm{K}$ and $\mathrm{P}$ levels in the soil surface, which were intensified by phosphogypsum application after 48 months. After 60 months, the effects of liming persisted for P and exchangeable K when combined with phosphogypsum (Fig. 4). Several authors have reported that liming can reduce potassium loss by leaching (Caires et al., 1998; Quaggio et al., 1993, 1982). This effect may be related to increased $\mathrm{pH}$-dependent negative charges caused by liming (Quaggio et al., 1982) and the charge alteration by divalent cations ( $\mathrm{Ca}$ and $\mathrm{Mg}$ ) by forming complexes with watersoluble organic ligands that are present in crop residues (Miyazawa et al., 1993). In such a scenario, the free charge would be occupied by $\mathrm{K}^{+}$, increasing the exchangeable $\mathrm{K}$ levels mainly in the upper soil layers (Caires et al., 1998).

The increase in the soil $\mathrm{pH}$, increasing the concentration and activity of $\mathrm{OH}$-ions in solution, promotes $\mathrm{Fe}$ and $\mathrm{Al}$ precipitation. In contrast, the precipitation of low soluble Fe- and Al-phosphates is decreased. In addition, negative charges are generated by hydroxyl deprotonation exposed in clays and organic matter, causing repulsion between the phosphate and the adsorbent surface (Macbride, 1994). Fageria and Baligar (2008) reported in Brazilian Oxisols a linear increase in available $\mathrm{P}$ with increased soil $\mathrm{pH}$ in the range of 5.3-6.9, indicating that the increased availability of $P$ in this interval was associated with the release of $\mathrm{P}$ ions from $\mathrm{Al}$ and Fe oxides, which are responsible for fixing this element in tropical soils. Thus, the annual phosphorus addition by fertilizers provided higher $\mathrm{P}$ availability by reducing the force with which $P$ was retained in the soil (Alvarado and Cajuste, 1993). The increased P availability with phosphogypsum may be related to the competitive adsorption of sulphate and phosphate in acidic conditions (Geelhoed et al., 1997); furthermore, phosphogypsum composition includes a small content of P.

The exchangeable Ca increased throughout the soil profile and to a greater extent in the upper soil layers with liming and phosphogypsum application (Fig. 5). Many studies have reported an increase in the soil exchangeable Ca under the influence of liming (Caires et al., 2011, 2004; Castro and Crusciol, 2013; de Oliveira and Pavan, 1996; Rheinheimer et al., 2000; Soratto and Crusciol, 2008b) or phosphogypsum (de Oliveira and Pavan, 1996; Rheinheimer et al., 2000,b; Soratto and Crusciol, 2008a,b). Because the two materials are sources of $\mathrm{Ca}$, we observed the effects of lime and phosphogypsum in the present study, with surface application contributing to increased calcium in the soil profile, confirming the results obtained by Caires et al. (2011, 2003), ) and Soratto and Crusciol (2008b).

Over time, there was a decrease in the exchangeable $\mathrm{Ca}$, similar to the effect that was observed for soil $\mathrm{pH}$ values (Fig. 2), which can be attributed to the extraction of Ca by previous crops. Caires et al. (2000) and Soratto and Crusciol (2008b) also found a reduction in exchangeable calcium levels over time, especially in the surface layers.

Liming increased the exchangeable Mg contents in the soil profile, whereas phosphogypsum application, with or without liming, reduced the exchangeable Mg contents (Fig. 5). Because dolomitic lime is also an Mg source, the observed increase in the Mg content in the soil profile was expected. Magnesium leaching has frequently been observed in studies with the surface application of phosphogypsum(Caires et al., 2006b, 2004, 2003, 1998; Gatiboni et al., 2003; Soratto and Crusciol, 2008b). This movement occurs via the association of cations with the $\mathrm{SO}_{4}{ }^{2-}$ anion, forming soluble ions pairs with a lower valence or neutral charge. In this way, these anions have a higher mobility and are more easily leached into the soil profile (Silva et al., 1998). However, in the present study, the use of dolomitic limestone maintained adequate levels of $\mathrm{Mg}$ in the soil for a long period, even when it was associated with phosphogypsum (Fig. 5).

Regarding the base saturation, the values were below the target of $70 \%$ in treatments with limestone in the $0-0.20 \mathrm{~m}$ layer, indicating that all limestone applied had reacted. The decrease in base saturation from 48 to 60 months is also an evidence of soil acidification. The highest values of base saturation as a function of phosphogypsum application without limestone were due to the increased calcium levels that were also observed in these treatments (Fig. 5). Similar effects were observed by Soratto and Crusciol (2008b).

\subsection{Soybean root growth}

The soybean root characteristics were influenced only by the year effect (Table 3). Although the descriptions of the soybean cultivars are similar, the cultivars had variable reactions to the chemical properties of acid soils. This result explains the differences in root development between the two seasons because there was no water restriction during the development of culture. Despite the changes in the soil chemical characteristics, mainly in aluminium and exchangeable calcium, in the surface and subsurface layers, the application of lime and/or phosphogypsum (Figs. 2 and 5) did not affect the root growth or diameter. Caires et al. (2001) found similar results when evaluating soybean root growth with surficial liming with or without phosphogypsum.

Ca plays an important role in root growth, but the Ca critical limits for root growth appear to be very low. Ritchey et al. (1982) showed that even in soils with low Ca levels, $1.0-1.5 \mathrm{mmol}_{\mathrm{c}} \mathrm{dm}^{-3}$, the seedling roots developed normally. In soybeans, root development occurred without any restrictions on soils with Ca of 8.5 $\mathrm{mmol}_{\mathrm{c}} \mathrm{dm}^{-3}$ (Rosolem and Marcello, 1998). This effect may be one explanation for the observed absence of the root system growth response for soybean in the present study.

Toxic concentrations of $\mathrm{Al}$ cause a reduction in the growth rate of roots, but plant genotypes vary with respect the reaction to $\mathrm{Al}$ present in acid soils. The Al toxicity of no-till systems is lower than that of conventional tillage (Salet et al., 1996). This lower toxic effect of $\mathrm{Al}$ in no-till systems has been attributed to the organic complexation of Al by soluble compounds present in the plant residues (Franchini et al., 1999).

\subsection{Plant nutrition}

The nutrient concentrations (Tables 4-6) were within the ranges considered adequate for crops (soybeans, oats and sorghum) with the exception of the $\mathrm{K}$ and $\mathrm{Zn}$ levels for soybeans, the $\mathrm{Ca}$, Mn and Fe levels for oat, and the Fe and Ca levels for sorghum, which were higher than the upper limit of these ranges (Ambrosano et al., 1997; Cantarella et al., 1997).

The highest $\mathrm{N}, \mathrm{K}, \mathrm{Mg}, \mathrm{S}, \mathrm{Zn}$ and Fe concentrations in soybean were observed in 2008/2009 (Table 4). This result can be explained by the higher nutrient levels in the soil before planting (48 months after reapplication).

The increased $\mathrm{N}$ content in soybean and sorghum (Tables 4 and 6) demonstrates the beneficial effects of lime and/or phosphogypsum on the symbiotic $\mathrm{N}_{2}$ fixation process in soybeans, the nitrate availability in the soil and $\mathrm{N}$ mineralization 
(Rosolem et al., 1990). The $\mathrm{N}_{2}$ symbiotic fixation efficiency is associated with greater Mo and smaller Mn availability by reducing the soil acidity (Caires et al., 2000). Thus, the amount of $\mathrm{N}$ extracted by the soybean crop was positively correlated with the increasing $\mathrm{Ca} / \mathrm{Mn}$ level in the leaves $(r=0.91, P<0.01)$, corroborating the results of Caires et al. (2001). The availability of nitrate may increase with increasing $\mathrm{pH}$ through liming because the activity of nitrification can increase with increased $\mathrm{pH}$ in acidic soils (Islam et al., 2006).

The increases in $\mathrm{Ca}$ and $\mathrm{Mg}$ contents in crops due to liming in established no-till systems (Tables 4-6) have also been observed by several authors (Caires et al., 2006c, 2001; Castro and Crusciol, 2013). These effects have been attributed to the increases in the exchangeable $\mathrm{Ca}$ and $\mathrm{Mg}$ availability in the soil profile. Phosphogypsum, being a Ca source, can also increase the Ca uptake by crops (Caires et al., 2006b, 2001).

The greater absorption of $\mathrm{S}$ by soybean and sorghum (Tables 4 and 6) must have been caused by the release of the adsorbed sulphate or by the increased mineralization of organic matter as a consequence of the increased soil pH in the surface layers by liming (Fig. 3). Phosphogypsum application also increased the absorption of $\mathrm{S}$ by crops because it is an excellent $\mathrm{S}$ source.

The reduction in $\mathrm{K}$ absorption by soybean (Table 4 ) was accompanied by an increase in $\mathrm{Ca}$ and $\mathrm{Mg}$ in the leaves, showing the antagonistic effect of $\mathrm{Ca}$ and $\mathrm{Mg}$ on $\mathrm{K}(r=-0.66, P<0.01)$. Similar results were observed by Caires et al. (2008a). The micronutrient contents in soybean ( $\mathrm{Cu}, \mathrm{Zn}$ and $\mathrm{Mn}$ ), oats ( $\mathrm{Mn}$ and $\mathrm{Fe}$ ) and sorghum (Mn) were also reduced with liming, with greater reductions observed in the phosphogypsum application for soybean $(\mathrm{Cu}$, $\mathrm{Zn}$ and $\mathrm{Mn}$ ) and black oat (Fe) (Tables 4-6). The increased soil pH with the use of limestone reduces the availability of some nutrients in the soil, particularly micronutrients (Malavolta et al., 1997). Sávio et al. (2011) also reported a reduction in the $\mathrm{Zn}$ and Mn concentrations in soybean grown in a no-till system with increased soil $\mathrm{pH}$ resulting from superficial liming.

\subsection{Yield components and grain yield}

The soybean yield was higher in 2009/2010 due to the higher number of seeds per pod (Table 4), which is characteristic of the selected cultivar (CD 216). The shoot dry matter and yield components increased with liming (Tables 4-6). Phosphogypsum application increased the yield components in sorghum and soybean when associated with liming. However, black oat experienced a reduction in the number of panicles per $\mathrm{m}^{2}$ with liming associated with phosphogypsum. These results reflect those observed for plant nutrition (Table 5). For sorghum, low temperatures extended the vegetative stage, and flowering occurred in a period with low water availability, mid-May 2010, which may have increased the spikelet sterility (Fornasieri Filho and Fornasieri, 2009).

The grain yield exhibited a strong correlation $(P<0.01)$ with population $(r=0.69)$ and 100 -grain weight $(r=0.84)$ in soybean, panicles per $\mathrm{m}^{2}(r=0.99)$ in black oat, and panicles per $\mathrm{m}^{2}(r=0.97)$ and grains per panicle $(r=0.98)$ in sorghum (Tables $4-6)$. Similar results were observed by Sávio et al. (2011) and Corrêa et al. (2008) for soybean and by Soratto and Crusciol (2008c) for black oat.

In subtropical regions, grain production is not always benefited by liming, and the greatest yield improvements in the present study were obtained under water stress conditions. Thus, the importance of studies under different climatic conditions is evident, as in the present study in a tropical region under "cerrado" (tropical savannah), the main grain-producing region in Brazil, liming consistently benefited grain production, even in years with regular rainfall distribution.

\section{Conclusion}

Superficial liming with or without phosphogypsum reduced the surface and subsurface soil acidity 5 years after application in a notill system. The movement of $\mathrm{Ca}^{2+}$ and $\mathrm{Mg}^{2+}$ from the surface layer into the subsoil over time was evident. Phosphogypsum application associated with liming increased the $\mathrm{Ca}^{2+}$ levels throughout the soil profile. Liming maintained high levels of $\mathrm{Mg}^{2+}$ throughout the soil profile with or without phosphogypsum application. The organic matter content increased with liming with or without phosphogypsum, indicating that in the long term, these practices can increase the $C$ accumulation in the system. Phosphogypsum application had a residual effect on the $\mathrm{SO}_{4}$-S levels, and high sulphate concentrations were observed in the subsoil after 5 years. Superficial liming improved crop nutrition and, when associated with phosphogypsum, increased Ca absorption by soybean and sorghum, as reflected in the increased productivity of these crops.

\section{Acknowledgments}

Thanks are due to the São Paulo Research Foundation (FAPESP, Proc. 2009/04126-3) for financial support and to the National Council for Scientific and Technological Development (CNPq) for an award for excellence in research to the second author.

\section{References}

Adams, F., Rawajfih, Z., 1977. Basaluminite and alunite: a possible cause of sulfate retention by acid soils. Soil Sci. Soc. Am. J. 41, 686-692.

Alvarado, J., Cajuste, L.J., 1993. Encalado y retención de fósforo en suelos derivados de cenizas volcánicas. Turrialba 43, 235-241.

Amaral, A.S., Anghinoni, I., Deschamps, F.C., 2004. Cover plant residues and mobility of dissolution products of surface applied lime. Rev. Bras. Ciênc. Solo $28,115-123$.

Ambrosano, E.J., Tanaka, R.T., Mascarenhas, H.A.A., van Raij, B., Quaggio, J.A., Cantarella, H., 1997. Leguminosas e oleaginosas. In: van Raij, B., Cantarella, H. Quaggio, J.A., Furlani, A.M.C. (Eds.), Recomendações de Adubação E Calagem Para O Estado de São Paulo. , 2nd ed. Bol. Tec. 100. IAC, Campinas, pp. 189-203.

Blevins, R.L., Murdock, L.W., Thomas, G.W., 1978. Effect of lime application on no-tillage and conventionally tilled corn. Agron. J. 70, 322-326.

Briedis, C., de Moraes Sá, J.C., Caires, E.F., de Fátima Navarro, J., Inagaki, T.M., Boer, A., de Oliveira Ferreira, A., Neto, C.Q., Canalli, L.B., Bürkner dos Sántos, J., 2012 Changes in organic matter pools and increases in carbon sequestration in response to surface liming in an oxisol under long-term no-till. Soil Sci. Soc. Am. J. 76, 151, http://dx.doi.org/10.2136/sssaj2011.0128.

Bronick, C.J., Lal, R., 2005. Soil structure and management: a review. Geoderma 124, 3-22, http://dx.doi.org/10.1016/j.geoderma.2004.03.005.

Caires, E.F., Chueiri, W.A., Madruga, E.F., Figueiredo, A., 1998. Changes in soil chemical characteristics by surface application of lime and gypsum and soybean response in no-tillage system. Rev. Bras. Ciênc. Solo 22, 27-34.

Caires, E.F., Fonseca, A.F., Mendes, J., Chueiri, W.A., Madruga, E.F., 1999. Corn, wheat and soybean yields as a function of the changes in soil chemical characteristics due to surface application of lime and gypsum under a no-tillage system. Rev. Bras. Ciênc. Solo 23, 315-327.

Caires, E.F., Banzatto, D.A., Fonseca, A.F., 2000. Surface application of lime under a no-tillage system. Rev. Bras. Ciênc. Solo 24, 161-169.

Caires, E.F., Fonseca, A.F., Feldhaus, I.C., Blum, J., 2001. Root growth and nutrient uptake by soybean as affected by lime and gypsum, under a no-tillage system. Rev. Bras. Ciênc. Solo 25, 1029-1040.

Caires, E.F., Blum, J., Barth, G., Garbuio, F.J., Kusman, M.T., 2003. Changes in chemical soil characteristics and soybean response to lime and gypsum applications in a no-tillage system. Rev. Bras. Ciênc. Solo 27, 275-286, http:// dx.doi.org/10.1590/S0100-06832003000200008.

Caires, E.F., Kusman, M.T., Barth, G., Garbuio, F.J., Padilha, J.M., 2004. Changes in soil chemical properties and corn response to lime and gypsum applications. Rev. Bras. Ciênc. Solo 28, 125-136.

Caires, E.F., Alleoni, L.R.F., Cambri, M.A., Barth, G., 2005. Surface application of lime for crop grain production under a no-till system. Agron. J. 97, 791, http://dx. doi.org/10.2134/agronj2004.0207.

Caires, E.F., Barth, G., Garbuio, F.J., 2006a. Lime application in the establishment of a no-till system for grain crop production in Southern Brazil. Soil Tillage Res. 89, 3-12, http://dx.doi.org/10.1016/j.still.2005.06.006.

Caires, E.F., Churka, S., Garbuio, F.J., Ferrari, R.A., Morgano, M.A., 2006b. Soybean yield and quality as a function of lime and gypsum applications. Sci. Agric. 63 370-379.

Caires, E.F., Garbuio, F.J., Alleoni, L.R.F., Cambri, M.A., 2006c. Surface lime application and black oat cover preceding corn and soybean crops under a no-till system. Rev. Bras. Ciênc. Solo 30, 87-98. 
Caires, E.F., Barth, G., Garbuio, F.J., Churka, S., 2008a. Soil acidity, liming and soybean performance under no-till. Sci. Agric. 65, 532-540.

Caires, E.F., Garbuio, F.J., Churka, S., Barth, G., Corrêa, J.C.L., 2008b. Effects of soil acidity amelioration by surface liming on no-till corn, soybean, and wheat root growth and yield. Eur. J. Agron. 28, 57-64, http://dx.doi.org/10.1016/j.eja.2007. 05.002 .

Caires, E.F., Pereira Filho, P.R.S., Zardo Filho, R., Feldhaus, I.C., 2008c. Soil acidity and aluminium toxicity as affected by surface liming and cover oat residues under a no-till system. Soil Use Manag. 24, 302-309, http://dx.doi.org/10.1111/ j.1475-2743.2008.00166.x.

Caires, E.F., Joris, H.A.W., Churka, S., 2011. Long-term effects of lime and gypsum additions on no-till corn and soybean yield and soil chemical properties in southern Brazil. Soil Use Manag. 27, 45-53, http://dx.doi.org/10.1111/j.14752743.2010.00310x

Camargo, O.A., van Raij, B., 1989. Movimento do gesso em amostras de latossolos com diferentes propriedades eletroquímicas. Rev. Bras. Ciênc. Solo 13 275-280.

Cantarella, H., van Raij, B., Camargo, C.E.O., 1997. Cereais. In: van Raij, B., Cantarella, H., Quaggio, J.A., Furlani, A.M.C. (Eds.), Recomendações de Adubação E Calagem Para O Estado de São Paulo. , 2nd ed. Bol. Tec. 100. IAC, Campinas, pp. 40-54.

Castro, G.S.A., Crusciol, C.A.C., 2013. Effects of superficial liming and silicate application on soil fertility and crop yield under rotation. Geoderma 195-196, 234-242, http://dx.doi.org/10.1016/j.geoderma.2012.12.006.

Chan, K.Y., Heenan, D.P., 1999. Lime-induced loss of soil organic carbon and effect on aggregate stability. Soil Sci. Soc. Am. J. 63, 1841-1844.

Ciotta, M.N., Bayer, C., Ernani, P.R., Fontoura, S.M.V., Albuquerque, J.A., Wobeto, C., 2002. Acidification of a south brazilian oxisol under no-tillage. Rev. Bras. Ciênc. Solo 26, 1055-1064.

Corrêa, J.C., Büll, L.T., Crusciol, C.A.C., Tecchio, M.A., 2008. Surface application of flue dust, aqueous lime, sewage sludge and limestone on soybean crop. Pesqui. Agropecu. Bras. 43, 1209-1219.

de Oliveira, E.L., Pavan, M.A., 1996. Control of soil acidity in no-tillage system for soybean production. Soil Tillage Res. 38, 47-57.

Ekenler, M., Tabatabai, M.A., 2003. Effects of liming and tillage systems on microbial biomass and glycosidases in soils. Biol. Fertil. Soils 39, 51-61, http:// dx.doi.org/10.1007/s00374-003-0664-8.

Ernani, P.R., Ribeiro, M.F.S., Bayer, C., 2004. Chemical modifications caused by liming below the limed layer in a predominantly variable charge acid soil. Commun. Soil Sci. Plant Anal. 35, 889-901, http://dx.doi.org/10.1081/css120030365.

Fageria, N.K., Baligar, V.C., 2008. Ameliorating soil acidity of tropical oxisols by liming for sustainable crop production. Adv. Agron. 99, 345-399, http://dx.doi. org/10.1016/S0065-2113(08)00407-0.

Fageria, N.K., Moreira, A., 2011. The role of mineral nutrition on root growth of crop plants. Adv. Agron. 110, 251-331, http://dx.doi.org/10.1016/B978-0-12385531-2.00004-9.

Fageria, N.K., Stone, L.F., 1999. Manejo da acidez de solos de cerrado e de várzea do Brasil, 1st ed. Embrapa-CNPAF, Santo Antonio de Goiás.

FAO, 2006. Guidelines for Soil Description, fourth ed. FAO, Rome.

Ferreira, D.F., 2008. SISVAR: a program for statistical analysis and teaching. Rev. Symp. 6, 36-41.

Fornasieri Filho, D., Fornasieri, J.L., 2009. Manual da cultura do sorgo. FUNEP, Jaboticabal.

Franchini, J.C., Malavolta, E., Miyazawa, M., Pavan, M.A., 1999. Chemical changes in acid soils after application of plant residues. Rev. Bras. Ciênc. Solo 23, 533-542.

Gatiboni, L.C., Saggin, A., Brunetto, G., Horn, D., Flores, J.P.C., Rheinheimer, D., dos, S., Kaminski, J., 2003. Changes in properties of a sandy soil under no tillage by surface liming. Ciênc. Rural 33, 283-290.

Geelhoed, J.S., Hiemstra, T., Van Riemsdijk, W.H., 1997. Phosphate and sulfate adsorption on goethite: single anion and competitive adsorption. Geochim. Cosmochim. Acta 61, 2389-2396, http://dx.doi.org/10.1016/s00167037(97)00096-3.

Gregory, P.J., 2006. Development and growth of root systems. In: Gregory, P.J. (Ed.), Plant Roots: Growth, Activity, and Interaction with Soils. Blackwell Publishing, pp. 45-79.

Hati, K.M., Swarup, A., Mishra, B., Manna, M.C., Wanjari, R.H., Mandal, K.G., Misra, A.K., 2008. Impact of long-term application of fertilizer, manure and lime under intensive cropping on physical properties and organic carbon content of an Alfisol. Geoderma 148, 173-179, http://dx.doi.org/10.1016/j.geoderma. 2008.09.015.

Islam, A., White, R.E., Chen, D., 2006. Nitrification activity in acid soils of north-eastern Victoria, Australia, as affected by liming and phosphorus fertilisation. Aust. J. Soil Res. 44, 739-744, http://dx.doi.org/10.1071/SR06058.

Juo, A.S.R., Dabiri, A., Franzluebbers, K., 1995. Acidification of a kaolinitic Alfisol under continuous cropping with nitrogen fertilization in West Africa. Plant Soil 171, 245-253, http://dx.doi.org/10.1007/BF00010278.

Macbride, M.B., 1994. Environmental Chemistry of Soils. Oxford University Press, New York.

Malavolta, E., Vitti, G.C., Oliveira, S.A., 1997. Avaliação do estado nutricional das plantas: princípios e aplicações, 2nd ed. Potafos, Piracicaba.

Miyazawa, M., Pavan, M.A., Calegari, A., 1993. Efeito de material vegetal na acidez do solo. Rev. Bras. Ciênc. Solo 17, 411-416.
Moreira, S.G., Kiehl, J.C., Prochnow, L.I., Pauletti, V., 2001. Liming under no-tillage and effects on soil acidity, soil nutrient availability and corn and soybean yield. Rev. Bras. Ciênc. Solo 25, 71-81.

Narro, L., Pandey, S., León, C., de Salazar, F., Arias, M.P., 2001. Implications of soil-acidity tolerant maize cultivars to increase production in developing countries: new perspectives. In: Ae, N., Arihara, J., Okada, K., Srinivasan, A. (Eds.), Plant Nutrient Acquisition. Springer, Tokyo, Japan, pp. 447-463.

Nolla, A., Anghinoni, I., 2006. Activity and chemical speciation of soil solution of an oxisol under no-tillage with different acidity conditions as affected by phosphorus addition. Rev. Bras. Ciênc. Solo 30, 955-963.

Pavan, M.A., Oliveira, E.L., 2000. Corretivos da acidez do solo: experiências no Paraná. In: Kaminski, J. (Ed.), Uso de Corretivos Da Acidez Do Solo No Plantio Direto. Núcleo Regional Sul da Sociedade Brasileira de Ciência do Solo, Pelotas, pp. 61-76.

Pavan, M.A., Bingham, F.T., Pratt, P.F., 1984. Redistribution of exchangeable calcium, magnesium, and aluminum following lime and gypsum applications to a Brazilian Oxisol. Soil Sci. Soc. Am. J. 48, 33-38.

Quaggio, J.A., Dechen, A.R., van Raij, B., 1982. Efeitos da aplicação de calcário e gesso sobre a produção de amendoim e lixiviação de bases do solo. Rev. Bras. Ciênc. Solo 6, 189-194.

Quaggio, J.A., van Raij, B., Gallo, P.B., Mascarenhas, H.A.A., 1993. Soybean responses to lime and gypsum and ion leaching into the soil profile. Pesqui. Agropecu. Bras. 28, 375-383.

Reeve, N.G., Sumner, M.E., 1972. Amelioration of subsoil acidity in Natal Oxisols by leaching of surface-applied amendments. Agrochemophysica 4, 1-6.

Rheinheimer, D.S., Santos, E.J.S., Kaminski, J., Bortoluzzi, E.C., Gatiboni, L.C., 2000. Changes in acid soil properties by superficial and incorporated liming on natural pasture. Rev. Bras. Ciênc. Solo 24, 797-805.

Rietra, R., Hiemstra, T., van Riemsdijk, W.H., 1999. Sulfate adsorption on goethite. J Colloid Interface Sci. 218, 511-521, http://dx.doi.org/10.1006/jcis.1999.6408.

Ritchey, K.D., Silva, S.E., Costa, V.F., 1982. Calcium deficiency in clayey B horizons of savannah Oxisols. Soil Sci. 133, 378-382.

Rosolem, C.A., Marcello, C.S., 1998. Soybean root growth and nutrition as affected by liming and phosphorus application. Sci. Agric. 55, 448-455.

Rosolem, C.A., Pereira, H.F.M., Bessa, A.M., Amaral, P.G., 1990. Nitrogen in soil and cotton growth as affected by liming and $\mathrm{N}$ fertilizer. In: Wright, R.J., Baligar, V.C., Murrmann, R.P. (Eds.), Plant-Soil Interactions at Low pH. Kluwer, Dordrecht, pp. 321-325

Salet, R.L., Kray, C.H., Fornari, T.G., Conte, E., Kochhann, R.A., Anghinoni, I., 1996. Variabilidade horizontal e amostragem de solo no sistema plantio direto. In: Reunião Sul-Brasileira de Ciência do Solo, 1. Sociedade Brasileira de Ciência do Solo, Lages, pp. 74-76.

Sávio, F.L., Silva, G.C., Teixeira, I.R., Mota, J.H., Borém, A., 2011. Nutrition and yield of soybean by lime and gypsum in soil with pasture degraded. Rev. Agrotecnologia 2, 19-31, http://dx.doi.org/10.12971/2179-5959.v02n01a02.

Soil Survey Staff, 2014. Keys to Soil Taxonomy, twelfth ed. United States Department of Agriculture, Soil Conservation, USA.

Silva, A.A., Vale, F.R., Fernandes, L.A., Neto, A.E.F., Muniz, J.A., 1998. Effects of $\mathrm{CaSO}_{4} / \mathrm{CaCO}_{3}$ ratios on the movement of nutrients in soil and cotton growth. Rev. Bras. Ciênc. Solo 22, 451-457.

Soratto, R.P., Crusciol, C.A.C., 2008a. Dolomite and phosphogypsum surface application effects on annual crops nutrition and yield. Agron. J. 100, 261-270, http://dx.doi.org/10.2134/agronj2007.0120.

Soratto, R.P., Crusciol, C.A.C., 2008b. Chemical soil attributes as affected by lime and phosphogypsum surface application in a recently established no-tillage system. Rev. Bras. Ciênc. Solo 32, 675-688.

Soratto, R.P., Crusciol, C.A.C., 2008c. Nutrition and grain yield of black oat as affected by surface application of lime and phosphogypsum at the establishment of no-tillage system. Rev. Bras. Ciênc. Solo 32, 715-725.

Soratto, R.P., Alexandre, C., Crusciol, C., Mello, F.F.C., 2010. Yield components of rice and bean cultivars as affected by lime and phosphogypsum applied in soil surface. Bragantia 69, 965-974.

Sumner, M.E., Noble, A.D., 2003. Soil acidification: the world story. In: Rengel, Z. (Ed.), Handbook of Soil Acidity. Marcel Dekker, New York, pp. 1-28.

van Raij, B., Cantarella, H., Quaggio, J.A., Furlani, A.M.C., 1997. Recomendações de adubação e calagem para o estado de São Paulo.

van Raij, B., Andrade, J.C., Cantarella, H., Quaggio, J.A., 2001. Análise química para avaliação da fertilidade de solos tropicais. Instituto Agronômico, Campinas.

Vieira, F.C.B., Bayer, C., Zanatta, J., Ernani, P.R., 2009. Organic matter kept Al toxicity low in a subtropical no-tillage soil under long-term (21-year) legume-based crop systems and N fertilisation. Aust. J. Soil Res. 47, 707-714.

Vitti, G.C., 1988. Enxofre no solo. In: Simpósio Sobre Interpretação de Análise Química de Solo E Planta Para Fins de Adubação. FCA-UNESP/FEPAF/ANDA/POTAFOS, Botucatu, pp. p39.

Walkley, A., Black, I.A., 1934. An examination of the degtjareff method for determining soil organic matter, and a proposed modification of the chromic acid titration method. Soil Sci. 37, 29-38, http://dx.doi.org/10.1097/00010694193401000-00003.

Westerhof, R., Buurman, P., van Griethuysen, C., Ayarza, M., Vilela, L., Zech, W., 1999. Aggregation studied by laser diffraction in relation to plowing and liming in the Cerrado region in Brazil. Geoderma 90, 277-290, http://dx.doi. org/10.1016/s0016-7061(98)00133-5. 